\title{
Climate Variability Impact on the Frequency of Occurrence of Mesoscale Convective Systems in Northern Nigeria
}

\section{Ochei MC* and Oluleye A}

Department of Meteorology and Climate Science, Federal University of Technology, Akure, Nigeria

\begin{abstract}
Mesoscale Convective Systems (MCSs) form an important component of meteorology in West Africa, and in particular, contribute substantially to precipitation totals. Several authors focused majorly on the contribution of these systems to precipitation and the damages that accompanied it. But in the event of current climate change, it is expected that storm occurrences especially over the tropics will also be impacted due to variability or changing in climate especially in Northern Nigeria which has experienced some extreme weather events over the years. The study was carried out in eight (8) different states within the savannah region of Nigeria. Monthly total rainfall, mean monthly temperature, relative humidity and daily Mesoscale Convective Systems (MCSs) (thunderstorms and line squalls) data of 31 years was used. Man-Kendall and Coefficient of variation (CV) method were used to analyze the data. There were various degrees of variations in some of the data analyzed based on the location of the station. The frequency of occurrence of these systems showed that its number (peals) decreases with an increasing latitude for stations north of $10^{\circ} \mathrm{N}$ with the north-eastern part of the country recording a decrease of almost one-third between 1981 and 2010. Hence, monsoon type of precipitation can be seen to be contributing more to the total annual rainfall in the northern part of Nigeria in contrast to earlier studies which gave Mesoscale Convective Systems (MCSs) $95 \%$ contribution rate.
\end{abstract}

Keywords: Climate variability; Mesoscale Convective Systems; Frequency

\section{Introduction}

Generally, the study of the weather and climatic elements of a region is vital for sustainable development of agriculture and planning. Particularly, temporal analyses for trends, fluctuations and periodicities of rainfall and temperature are deemed necessary as such can indirectly furnish the "meteorological" event or status of a region. Agriculture, as one of the major sectors that has a high contribution to the Gross Domestic Product of Nigeria, is principally rain-fed. And the rainfall supplies are gotten mostly from mesoscale convective systems as it contributes about $80 \%$ of the annual total rainfall in Nigeria which conforms with the studies of many authors which have shown that the greatest proportion of the annual rainfall of West Africa countries comes from deep convective systems [1,2]. This has been discovered to be largely due to the occurrence of MCSs (thunderstorm and squall line) that produce majority of the summer rainfall [2-4].

Line squalls and thunderstorms are regular phenomena within the tropics and are often accompanied by rain, destructive violent winds, lightning, thunders and hail, thereby posing serious hazardous problems to man and his socio-economic activities. Omotosho [5] noted the West African mesoscale systems are not as violent as their United States counterparts, but they are being studied because of their socio-economic importance. Apart from contributing to more than half of the total annual precipitation where they occur, thunderstorm has been a great threat to man especially in the area of shelter, agriculture and aviation. Turbulence and icing are associated with well-developed cumulonimbus cloud, while strong winds, heavy rains, hails and lightning constitute additional hazards to both flight and humans.

Omotosho [2] however showed that percentage contribution of thunderstorm rainfall in Nigeria decreases with increasing latitude while squall rainfall is at a maximum around $9^{\circ} \mathrm{N}$. In the tropics, thunderstorms and squall lines are responsible for at least $70 \%$ of the rainfall in the coastal region (south) and over 95\% in the Sahel (north). But this work was improved upon by Orisakwe [6] which saw mesoscale convective systems contributing as low as $72.5 \%$ to the total precipitation in Nigeria with thunderstorm having as much as $45.7 \%$ and squall line having $26.8 \%$ contribution. Unsurprisingly, Ochei et al. [7] also showed that the occurrence of thunderstorms tends to be greatly reduced over Maiduguri (North-eastern Nigeria) than over Sokoto (North-western Nigeria). However, further studies [8-11] have revealed the occurrence of upper-level downdrafts at the sides of the upper portion of updrafts.

Most works on mesoscale convective systems ranges from its contribution to total precipitation $[2,6,12]$, frequency of occurrences of such systems [7] to the damages it has caused over-time [13-15], but none has been written explicitly on the implication of the changing climate on the frequency of occurrence of these mesoscale convective systems. This is an area where changing climate variables, have the tendency of affecting either negatively (positively), by decreasing (increasing) the number of occurrence of thunderstorm in a given time frame. This work has the potential of revealing the changing climate variables affecting the frequency of mesoscale convective systems vis-àvis the amount of rainfall seasonally.

Northern Nigeria, the domain of study, lies between latitude $8-14^{\circ} \mathrm{N}$ and longitude $3-15^{\circ} \mathrm{E}$. The zone is bounded by Niger republic to the north, Benin republic to the west and Cameroon to the east. It has a

*Corresponding author: Ochei MC, Department of Meteorology and Climate Science, Federal University of Technology, Akure, Nigeria, Tel: +234-903-5431474; E-mail: mcochei@futa.edu.ng

Received August 20, 2017; Accepted November 10, 2017; Published November 15,2017

Citation: Ochei MC, Oluleye A (2017) Climate Variability Impact on the Frequency of Occurrence of Mesoscale Convective Systems in Northern Nigeria. J Climatol Weather Forecasting 5: 213. doi:10.4172/2332-2594.1000213

Copyright: ( 2017 Ochei MC, et al. This is an open-access article distributed under the terms of the Creative Commons Attribution License, which permits unrestricted use, distribution, and reproduction in any medium, provided the original author and source are credited. 
Citation: Ochei MC, Oluleye A (2017) Climate Variability Impact on the Frequency of Occurrence of Mesoscale Convective Systems in Northern Nigeria. J Climatol Weather Forecasting 5: 213. doi:10.4172/2332-2594.1000213

Page 2 of 13

population of $75,025,166$ million people (2008 estimate) [16] which is equivalent to about $53.6 \%$ of the country's total population and covers an area of $719,435 \mathrm{sq} . \mathrm{km} \sim 79 \%$ of Nigeria landmass. Stations were selected at different latitudes (with four stations north of $10^{\circ} \mathrm{N}$ known as 'transition zone' while the other four stations are south of $10^{\circ} \mathrm{N}$ ) and almost all geo-political zones within this region/zone were well represented (Figure1).

Using the thunderstorm and squall line (MCSs) dataset, this work was aimed at presenting a synoptic view of the frequency or rate of occurrence of these systems in the face of changing climate variables. In order to achieve this, the following objectives were drawn up which include to:

(1) Analyse the trend of some meteorological parameters (Temperature, Relative Humidity and Rainfall amount to be precise) in the selected stations,

(2) Determine the trends and effect of changing climate on the MCSs at different stations; and

(3) Establish the spatio-temporal pattern of MCSs (thunderstorms and squall line) in the Northern Nigeria.

\section{Data and Methods}

Monthly mean temperature and relative humidity data as well as monthly rainfall data for a period of thirty-one (31) years (19802010) except Abuja station which started operations in 1982 and daily Mesoscale Convective Systems data (thunderstorm and squall line) spanning a period of thirty (30) years (1981-2010) extracted from the daily record of observation of Nigerian Meteorological Agency, Oshodi, Lagos, constituted the main data.

In this register of observations are recorded the times of start and end of rainfall events; presented under three columns $(0600 \mathrm{hr}$ to $1800 \mathrm{hr}, 1800 \mathrm{hr}$ to $0600 \mathrm{hr}$ next day and $0600 \mathrm{hr}$ to $06 \mathrm{hr}$ next day), the rainfall amount and the meteorological system (e.g. Squall lines, Thunderstorm or Monsoon), responsible for the rain. It is through the column for weather we were able to ascertain if the rainfall amount of that day was as a result of MCSs (thunderstorms and/or squall line) or monsoon type of precipitation.

In order to study the frequency of occurrence of thunderstorm, the total monthly and yearly number of thunderstorm occurrence were determined from the daily information from the data sheet. And to look at the effect of climate change on each station, the thirty (30) years data set was divided into three decades between 1981 and 2010 so as to investigate trends of these systems over the station.

But in order to compare the degree of variation of the frequency of occurrence of these systems, the coefficient of variation was calculated using the formula below:

$$
\text { C.V. }=\frac{\delta}{\sigma} \times 100
$$

where C.V. is the coefficient of variation, $\delta$ is the standard deviation, while $\sigma$ is the mean of the frequency.

\section{Results and Discussions}

\section{Discussion}

Dividing the eight (8) stations of temperature trend into four (4) equal parts with Figures 2-5 to be stations south of $10^{\circ} \mathrm{N}$ while Figures 6-9 are stations north of $10^{\circ} \mathrm{N}$, it can been seen that almost all the stations recorded an increasing trend which is an attestation of Odjugo and Ikhuoria [16], and Adefolalu [17] studies which showed that the increasing temperature in the semi-arid region of central and extreme northern states may be attributed to increasing evapo-transpiration, drought and desertification in Nigeria. But Ilorin Figure 2 recorded a decreasing trend and this can be attributed to its closeness to the

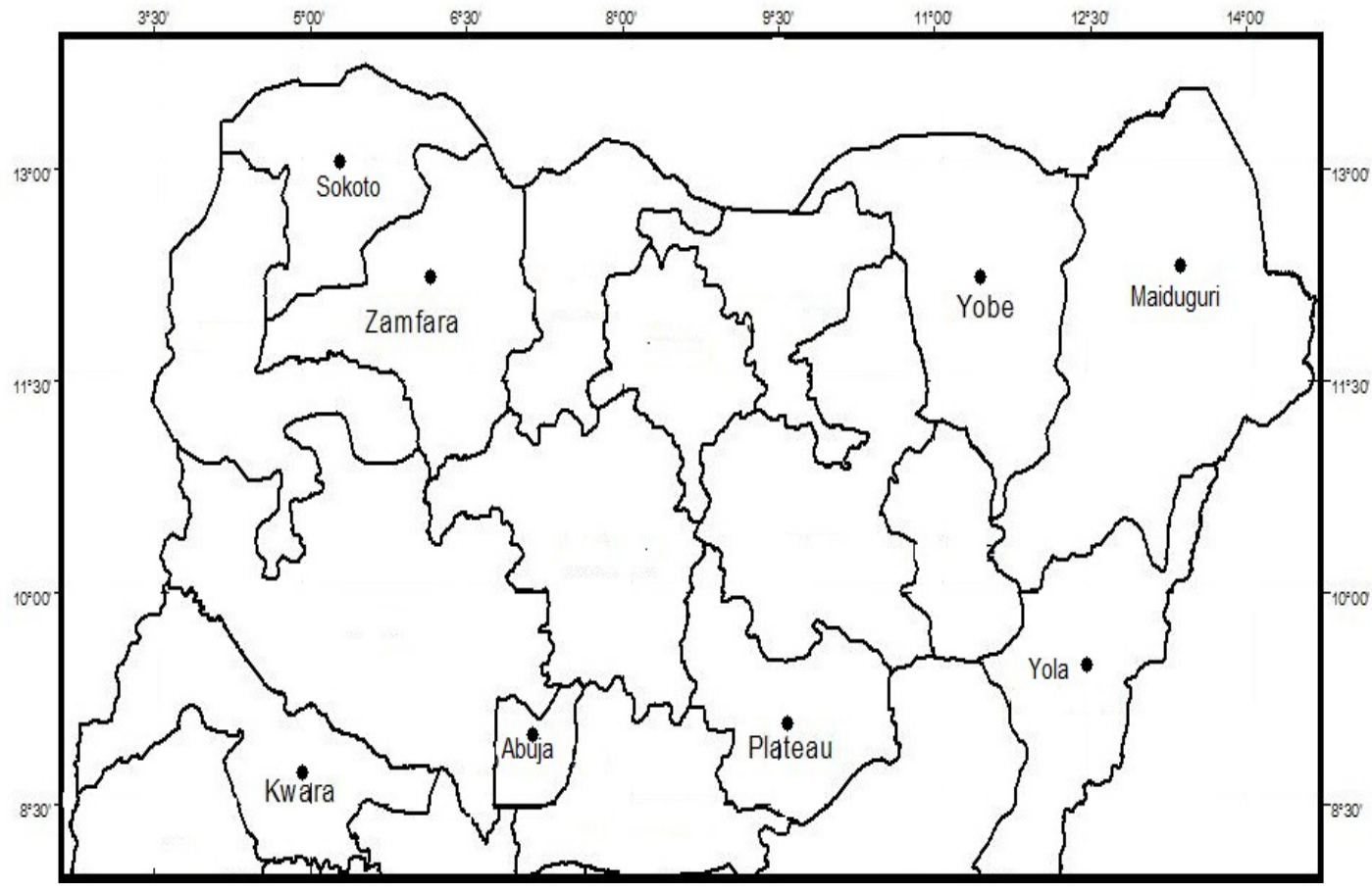

Figure 1: Map of Nigeria showing the study area (northern Nigeria). 
Citation: Ochei MC, Oluleye A (2017) Climate Variability Impact on the Frequency of Occurrence of Mesoscale Convective Systems in Northern Nigeria. J Climatol Weather Forecasting 5: 213. doi:10.4172/2332-2594.1000213

Page 3 of 13

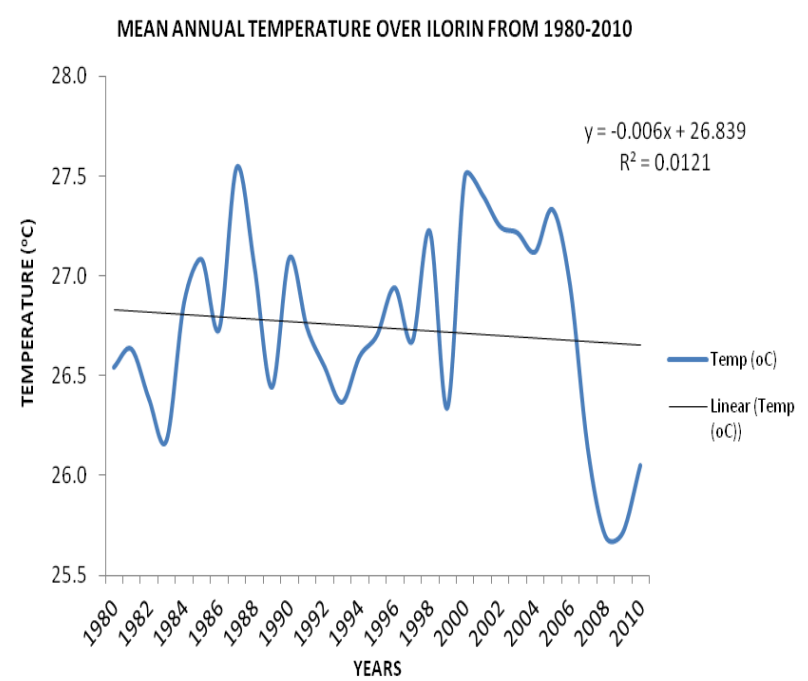

Figure 2: Mean annual temperature of florin (1980-2010).

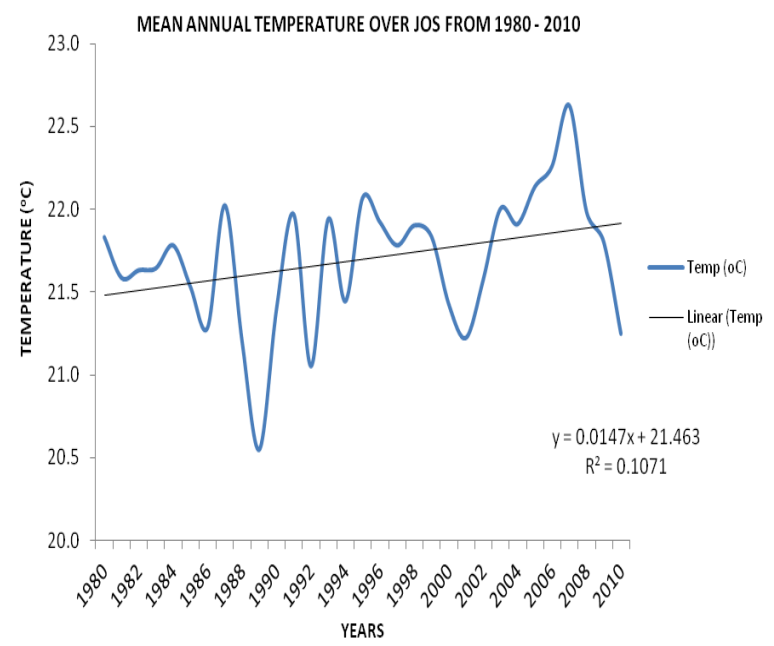

Figure 3: Mean annual temperature of Jos (1980-2010).

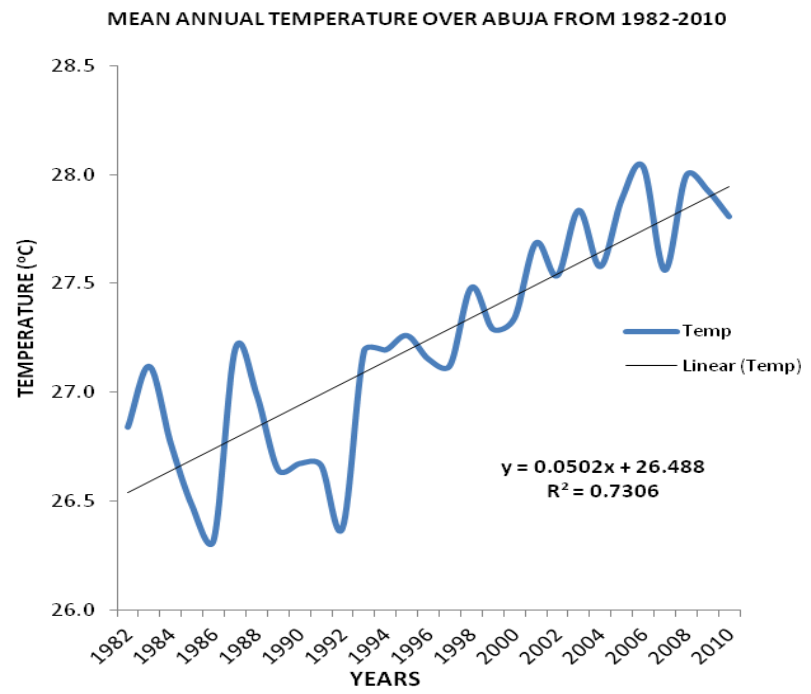

Figure 4: Mean annual temperature of Abuja (1982-2010).

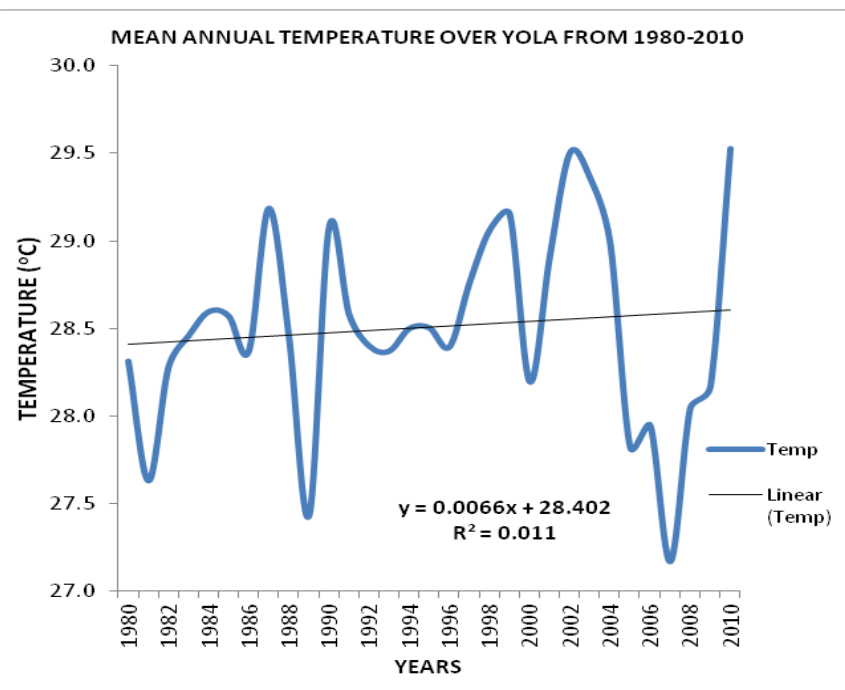

Figure 5: Mean annual temperature of Yola (1980-2010).

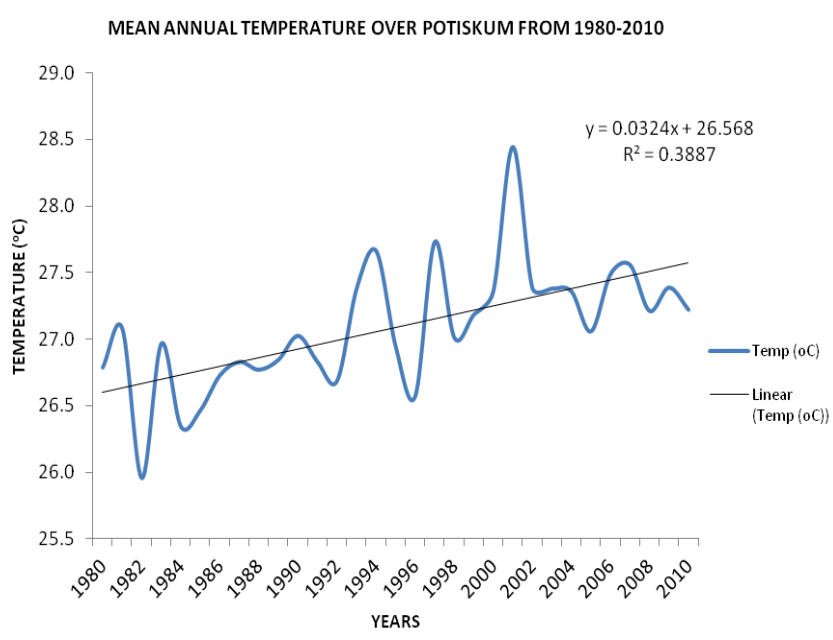

Figure 6: Mean annual temperature of Potiskum (1980-2010).

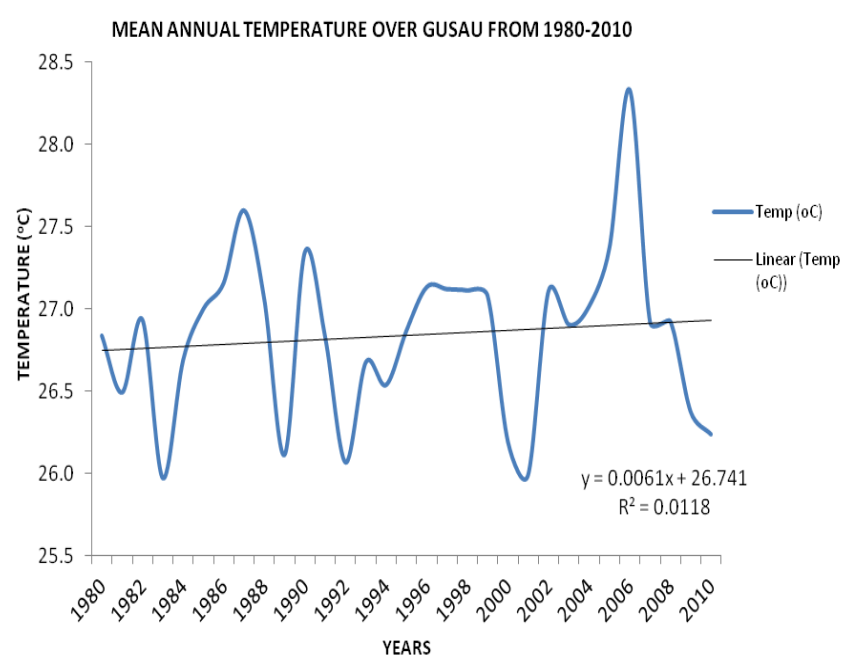

Figure 7: Mean annual temperature of Gusau (1980-2010).

$\mathrm{J}$ Climatol Weather Forecasting, an open access journal

ISSN: 2332-2594

Volume $5 \cdot$ Issue $3 \cdot 1000213$ 
Citation: Ochei MC, Oluleye A (2017) Climate Variability Impact on the Frequency of Occurrence of Mesoscale Convective Systems in Northern Nigeria. J Climatol Weather Forecasting 5: 213. doi:10.4172/2332-2594.1000213

rainbelt of Lagos state. Gusau (Figure 7) recorded the least increasing trend of about $11 \%$ correlation, while Potiskum and Sokoto on Figures 6 and 9 respectively recorded the highest correlation value of about $62 \%$. But coming down to further inland around the central states below the $10^{\circ} \mathrm{N}$ (marked as the transition zone), Abuja as represented by Figure 4 showed the highest trend in temperature of about $85 \%$ increase over a twenty-nine (29) years period which will amount to about $2.9 \%$ increase annually (Figures 10-13).

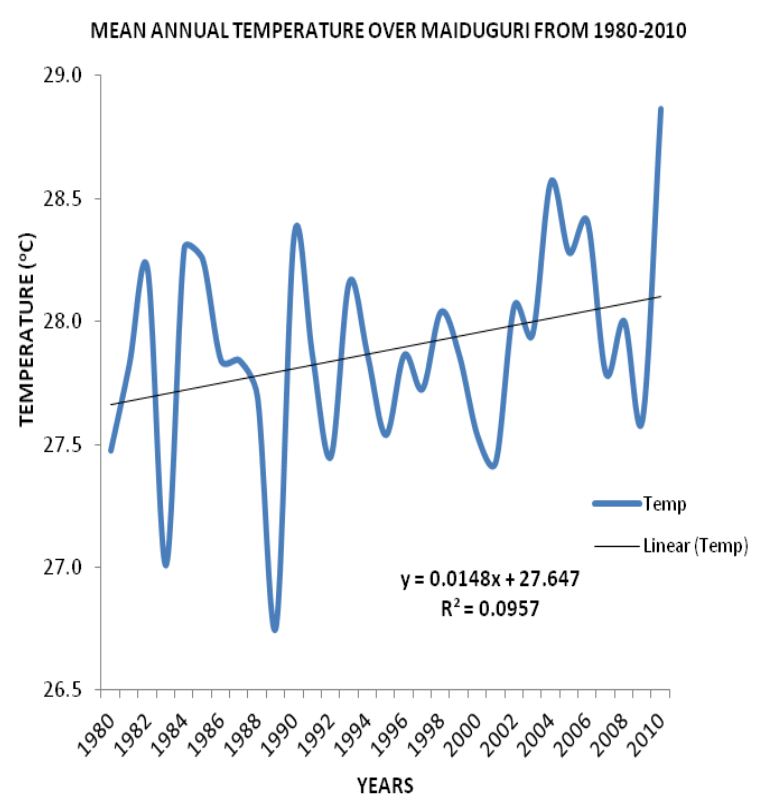

Figure 8: Mean annual temperature of Maiduguri (1980-2010).

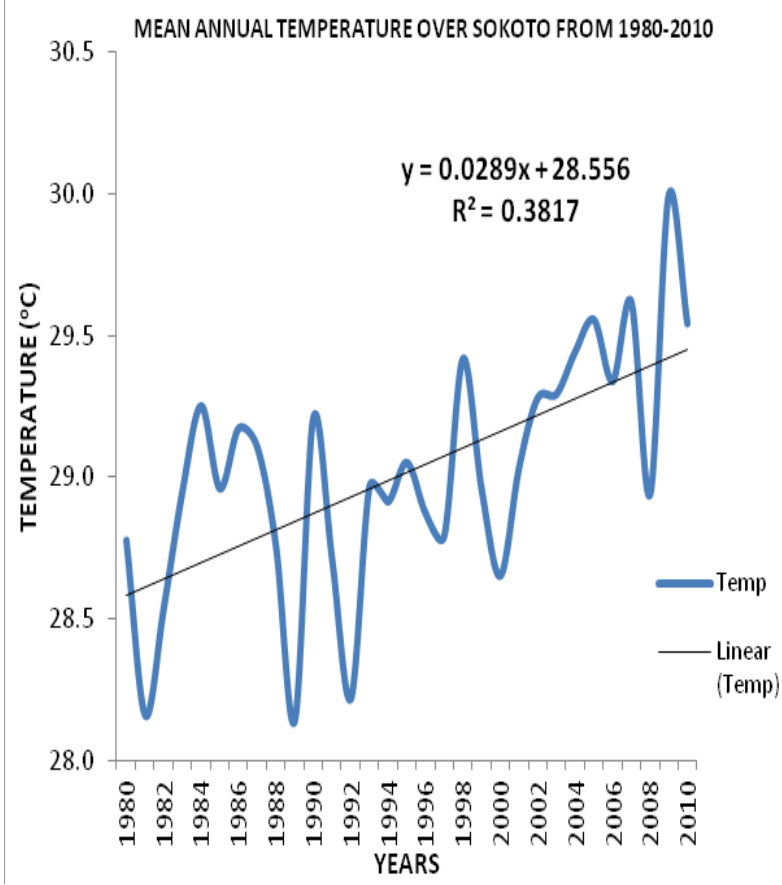

Figure 9: Mean annual temperature of Sokoto (1980-2010).

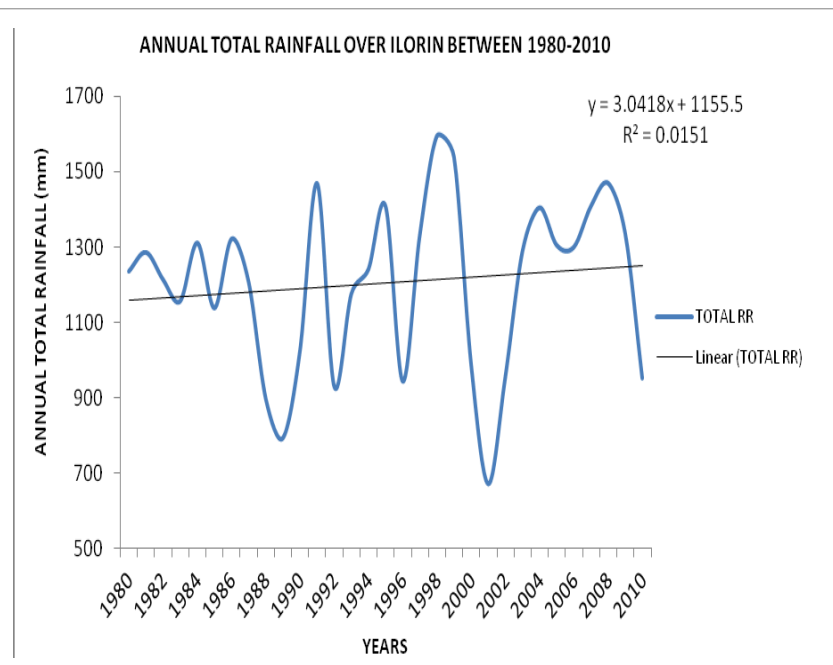

Figure 10: Annual total rainfall of llorin (1980-2010).

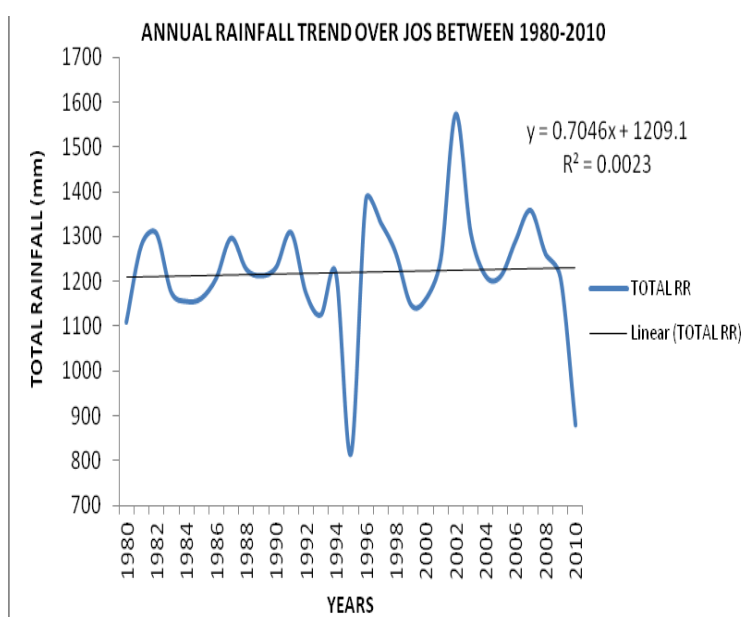

Figure 11: Annual total rainfall of Jos (1980-2010).

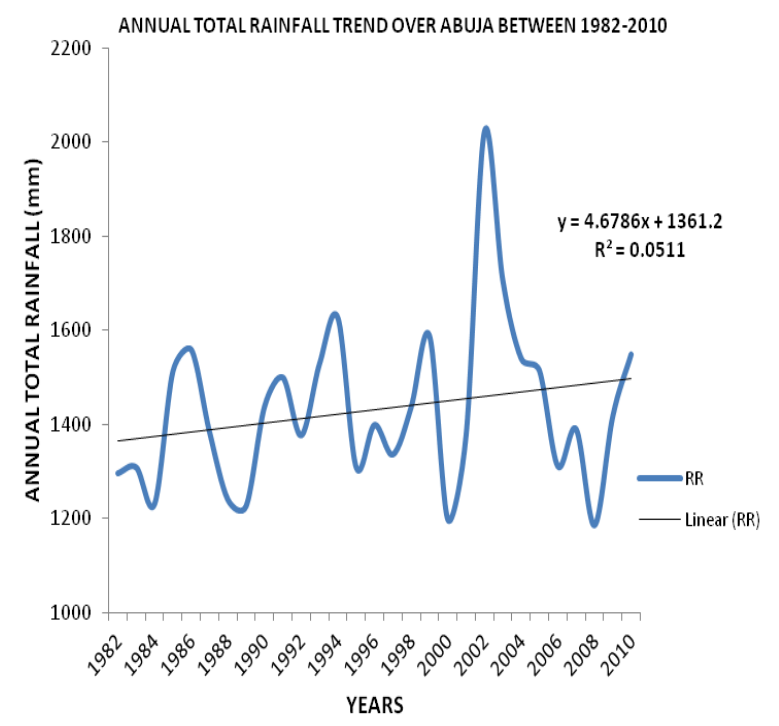

Figure 12: Annual total rainfall of Abuja (1982-2010). 
Citation: Ochei MC, Oluleye A (2017) Climate Variability Impact on the Frequency of Occurrence of Mesoscale Convective Systems in Northern Nigeria. J Climatol Weather Forecasting 5: 213. doi:10.4172/2332-2594.1000213

Page 5 of 13

Areas north of $10^{\circ} \mathrm{N} 9$ (Figures 14-17): The rainfall trend for the stations (Figures 10-17) showed that virtually all the stations have an increasing trend which conform with the work of Ayansina et al. [18], that investigated the seasonal rainfall variability in Guinea savannah part of Nigeria and concluded that rainfall variability continue to be on the increase as an element of change in climate. And this can be seen among the Guinea savannah states of Ilorin (Figure 10) and Abuja (Figure 12) which recorded the highest increasing trend amongst

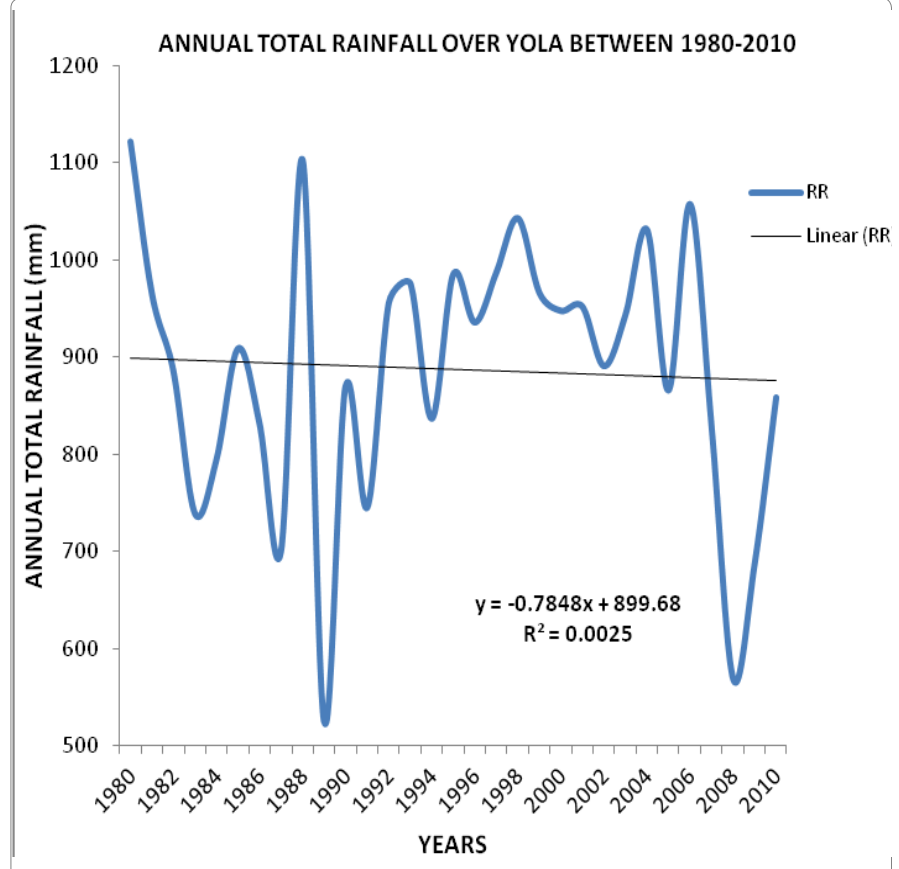

Figure 13: Annual total rainfall of Yola (1980-2010).

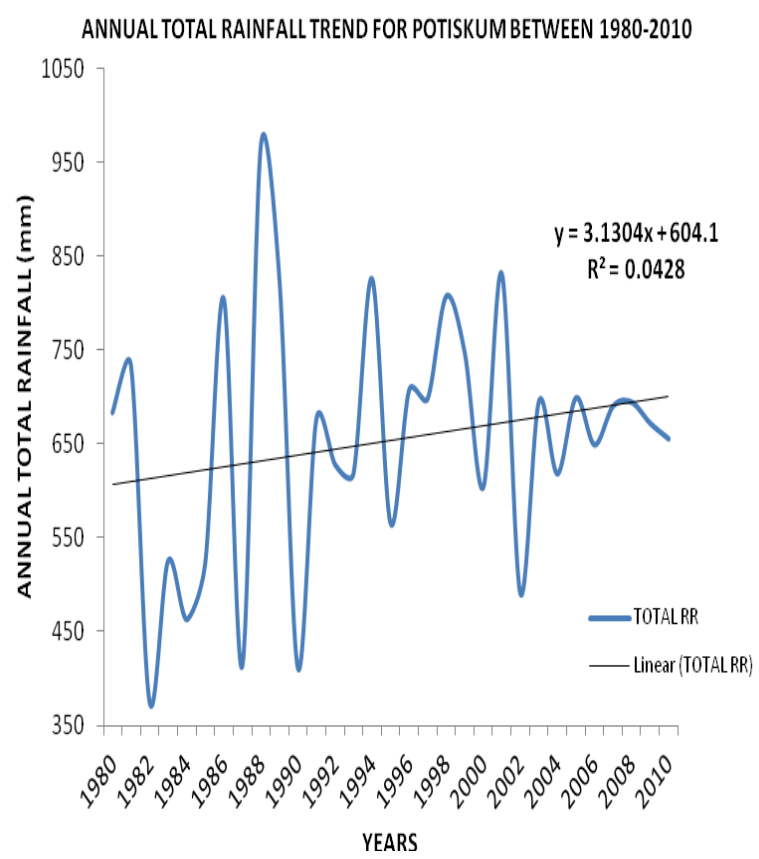

Figure 14: Annual total rainfall of Potiskum (1980-2010).

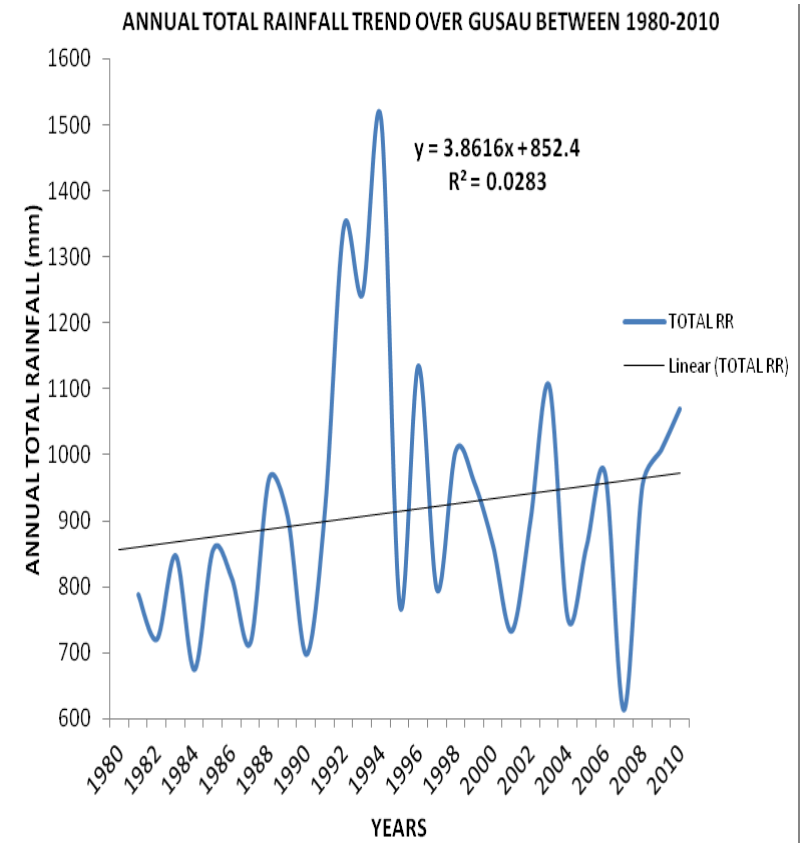

Figure 15: Annual total rainfall of Gusau (1980-2010).

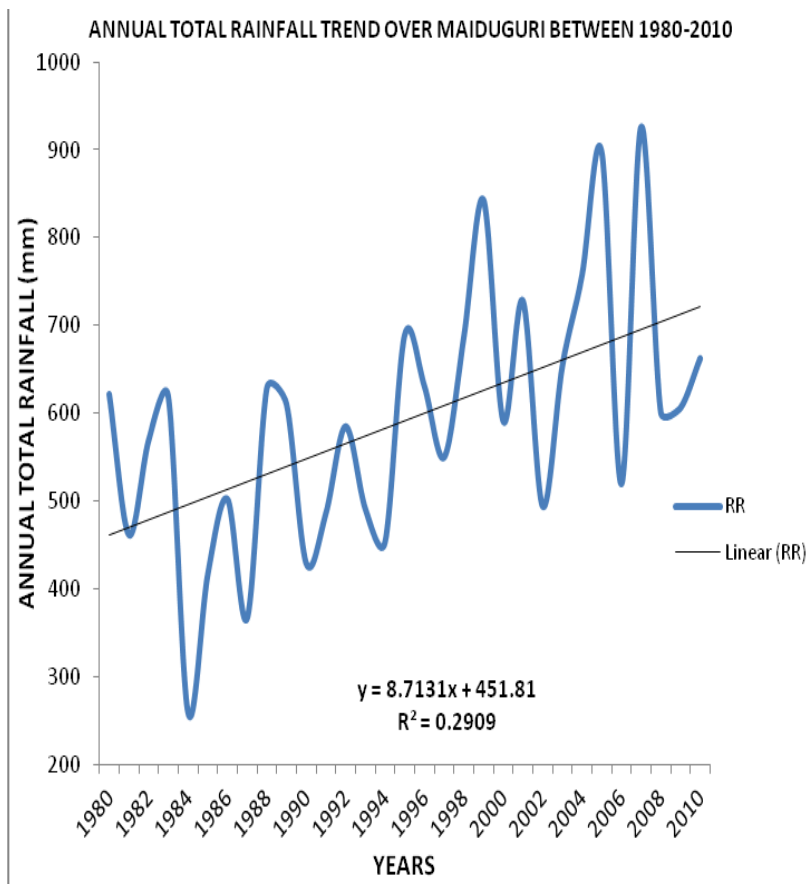

Figure 16: Annual total rainfall of Maiduguri (1980-2010).

the inland stations with about $12 \%$ and $23 \%$ correlation respectively while the sahelian region of Maiduguri and Sokoto (Figures 16 and 17 respectively) recorded the highest increasing trend amongst the stations in the extreme northern Nigeria (Sudan and Sahel region). But Ekpoh [19] conducted station analysis using long-term rainfall data for Katsina, Zaria and Kano to test for trend using the 5-year running mean and the results from the study indicated a decrease in annual rainfall in the three stations from 1969 up to 1999. Thus, Yola (Figure 
Citation: Ochei MC, Oluleye A (2017) Climate Variability Impact on the Frequency of Occurrence of Mesoscale Convective Systems in Northern Nigeria. J Climatol Weather Forecasting 5: 213. doi:10.4172/2332-2594.1000213

13) recorded a decreasing trend of about $5 \%$ correlation. Summarily, stations north of $10^{\circ} \mathrm{N}$ (Figures 10-13) recorded an average increasing trend of about $36.25 \%$ correlation within 1980-2010, while the stations south of $10^{\circ} \mathrm{N}$ (Figures 14-17) had an average increasing trend of about $8.75 \%$ correlation within the same period of years. Hence, the figures above showed a distant $27.5 \%$ difference between stations north of $10^{\circ} \mathrm{N}$ and those stations south of $10^{\circ} \mathrm{N}$ (Figures 18-21).

Areas north of $10^{\circ} \mathrm{N}$ (Figures 22-25): Adefolalu [20] illustrated the significant differences in mean value of relative humidity between

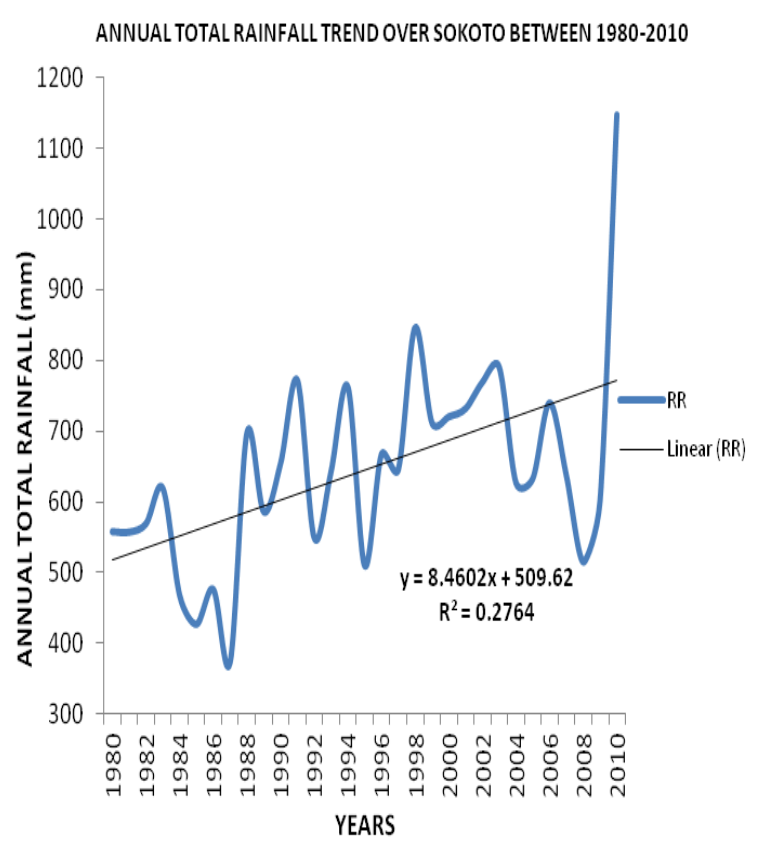

Figure 17: Annual total rainfall of Sokoto (1980-2010).

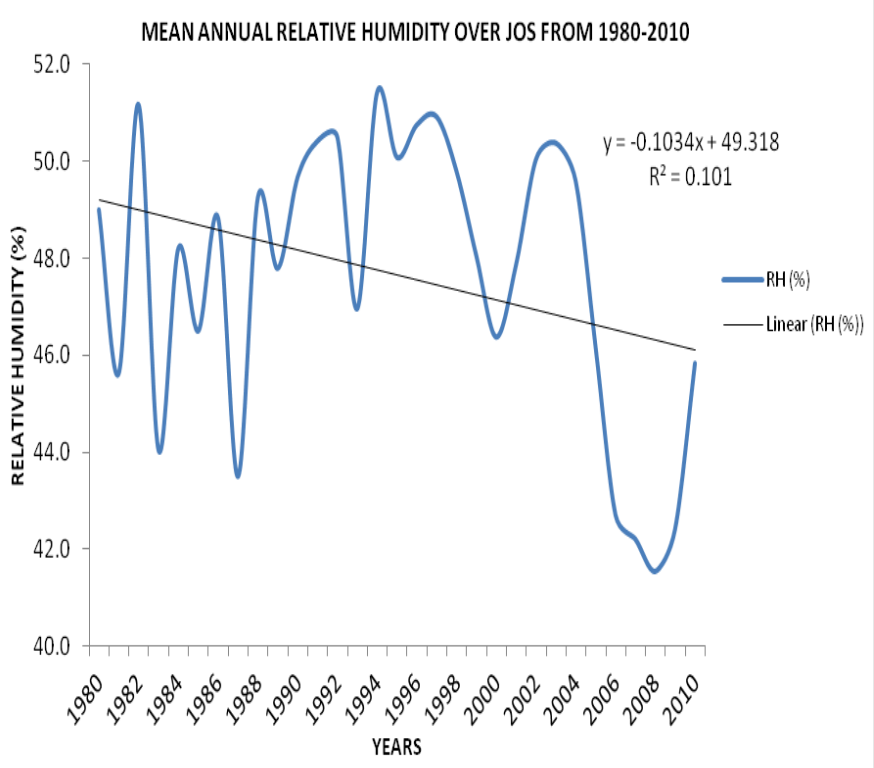

Figure 18: Mean annual relative humidity of Ilorin (1980-2010).

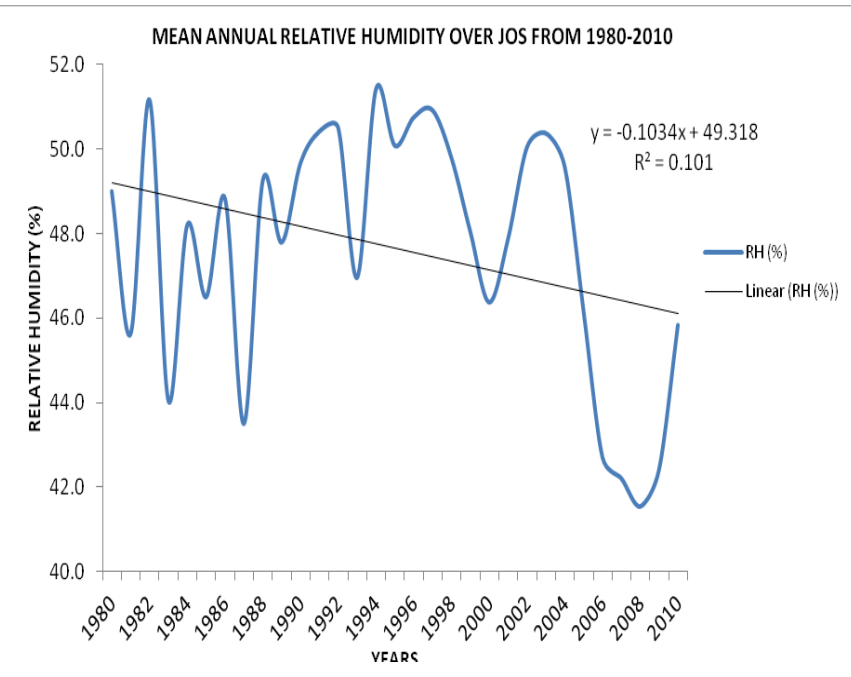

Figure 19: Mean annual relative humidity of Jos (1980-2010).

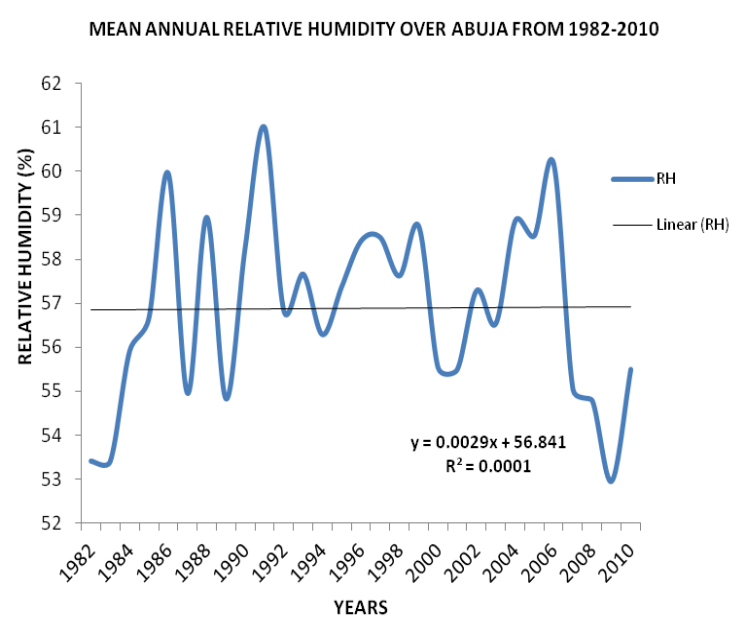

Figure 20: Mean annual rel. humidity of Abuja (1982-2010).

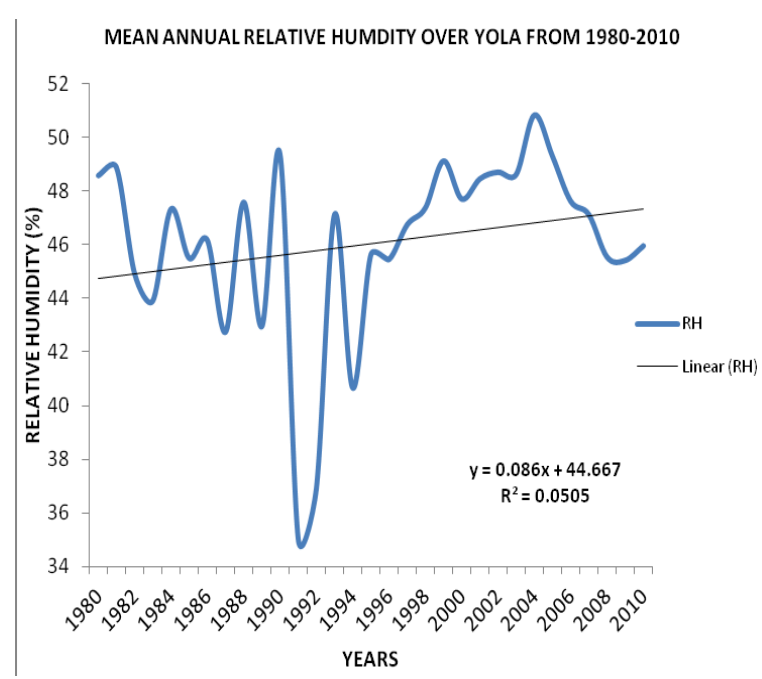

Figure 21: Mean annual relative humidity of Yola (1980-2010). 
Citation: Ochei MC, Oluleye A (2017) Climate Variability Impact on the Frequency of Occurrence of Mesoscale Convective Systems in Northern Nigeria. J Climatol Weather Forecasting 5: 213. doi:10.4172/2332-2594.1000213

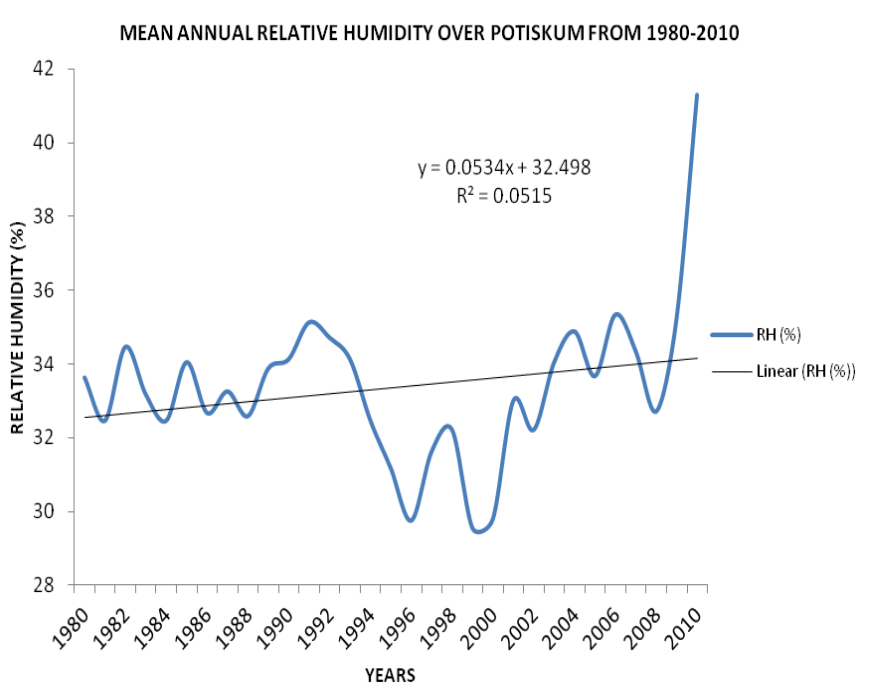

Figure 22: Mean annual rel. humidity of Potiskum (1980-2010).

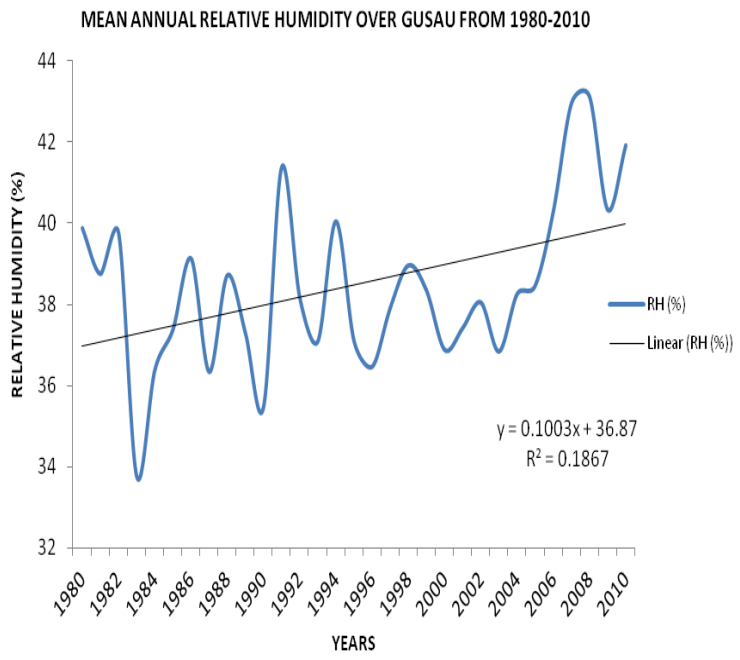

Figure 23: Mean annual rel. humidity of Gusau (1980-2010).

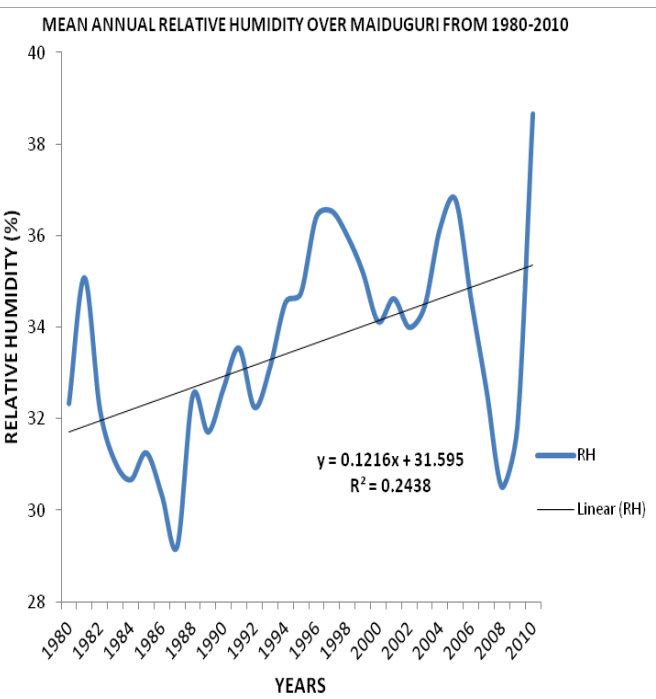

Figure 24: Mean annual rel. humidity of Maiduguri (1980-2010).

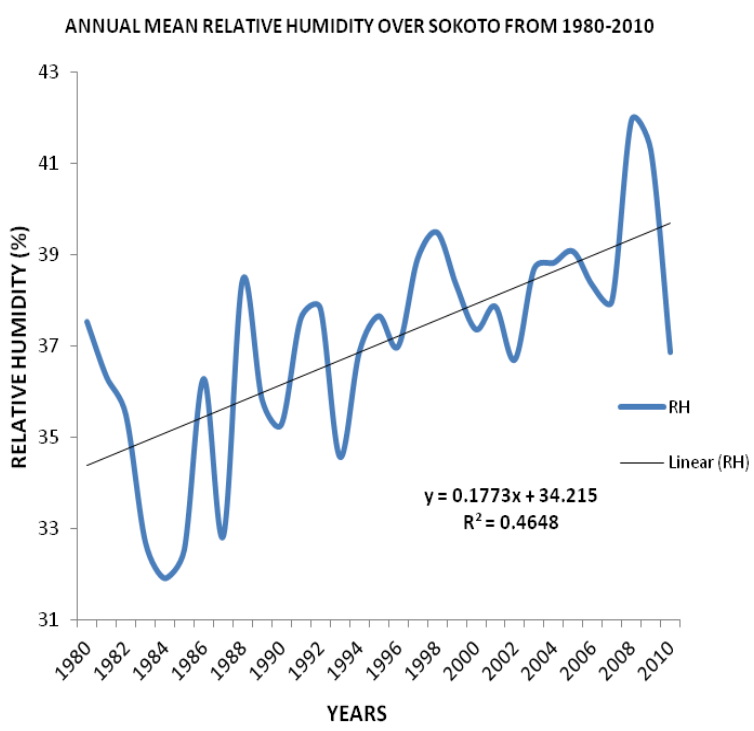

Figure 25: Mean annual relative humidity of Sokoto (1980-2010).

north and south; with the seasonal variations being more pronounced in the north than the southern part of Nigeria. And this can be seen in all the stations north of $10^{\circ} \mathrm{N}$ (Figures 22-25) which recorded an average increasing trend on their correlation of about $45.75 \%$ across the four stations compared to the other four stations south of $10^{\circ} \mathrm{N}$ (Figures 18-21) which recorded an increasing average correlation as low as $3.5 \%$; and this amount to about $42.25 \%$ difference in this two zones within the same region. Jos (Figure 19) is the only station that recorded a decreasing trend amongst the whole eight (8) stations with about $32 \%$ correlation. While Abuja (Figure 20) had the least increasing trend as low as $1 \%$ correlation which can be said to be negligible when compared over the period of twenty-nine years (Figures 21-25).

All stations north of $10^{\circ} \mathrm{N}$ exhibited a single peak which can be said to be in agreement with Riehl [21], Thompson [22] and Garnier [23]. There also seems to be a continuous decrease in the number of the convective systems between 1981 and 2010 on a decadal basis. Typical example of this can be seen at Potiskum (Figures 26-28) and Maiduguri (Figures 29-31) with only Sokoto (Figures 32-34) having a constant number/frequency of occurrences of convective systems over the thirty (30) years period. Though, Jos station which is south of $10^{\circ} \mathrm{N}$ also exhibited a single peak in the frequency of occurrences of the convective systems; and this is in contrast to Omotosho [2] study.

But all stations south of $10^{\circ} \mathrm{N}$ except Jos stations (Figures 35-37) complies with earlier studies of [21-24] which stated that areas south of $10^{\circ} \mathrm{N}$ exhibits double maxima but diminishes northward from the coast and becomes single peak. These double peaks occurred between May, June and July with the little dry season (LDS) occurring around July and August and it is almost as frequent as its non-occurrence which confirm to Eludoyin et al. [25] studies of monthly rainfall distribution in Nigeria between 1985-1994 and 1995-2004 and noticed some fluctuations in most months within the decades. In contrast to the decreasing frequency of occurrences of these convective systems over stations north of $10^{\circ} \mathrm{N}$, stations south of $10^{\circ} \mathrm{N}$ recorded an increasing value in the frequency of occurrences of the convective systems as seen in Ilorin (Figures 3840) from 90peals in the first decade to 120peals in the last decade and Abuja (Figures 41-46) from 100peals in the first decade to 165peals in the last decade; but Yola (Figures 47-49) on latitudes $09.14^{1} \mathrm{~N}$ recorded 
Citation: Ochei MC, Oluleye A (2017) Climate Variability Impact on the Frequency of Occurrence of Mesoscale Convective Systems in Northern Nigeria. J Climatol Weather Forecasting 5: 213. doi:10.4172/2332-2594.1000213

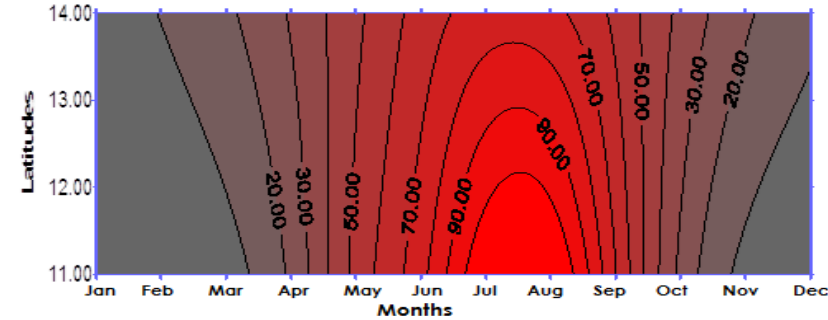

Figure 26: Spatio-temporal occurrences of MCS over Potiskum from 19811990.

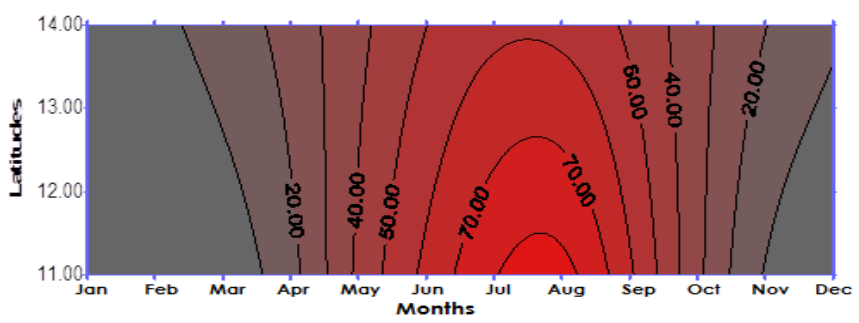

Figure 27: Spatio-temporal occurrences of MCS over Potiskum from 1991-2000.

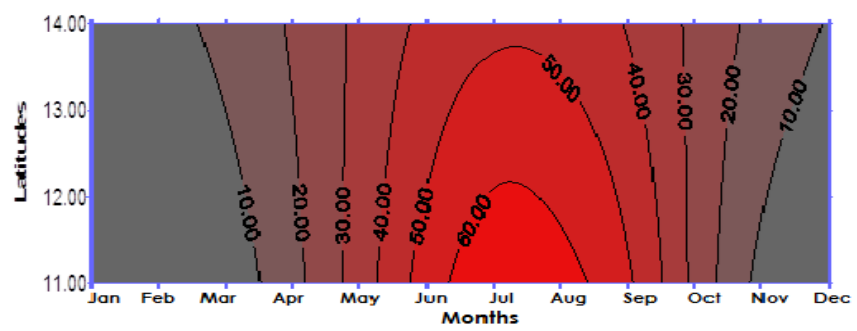

Figure 28: Spatio-temporal occurrences of MCS over Potiskum from 2001-2010.

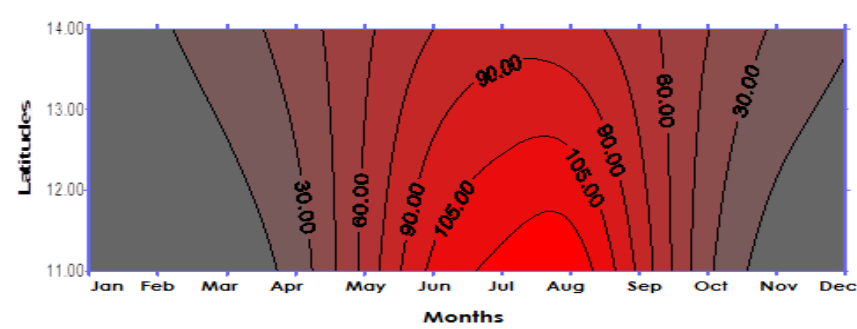

Figure 29: Spatio-temporal occurrences of MCS over Maiduguri from 19811990.

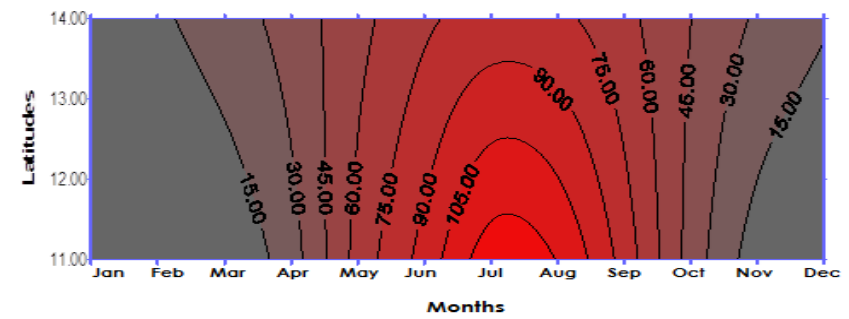

Figure 30: Spatio-temporal occurrences of MCS over Maiduguri from 19912000 .

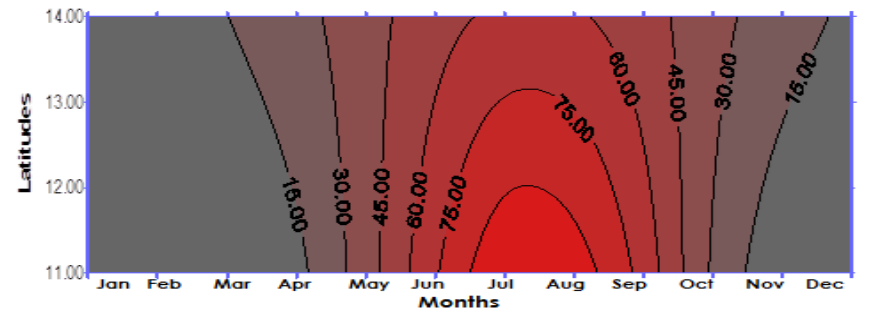

Figure 31: Spatio-temporal occurrences of MCS over Maiduguri from 20012010.

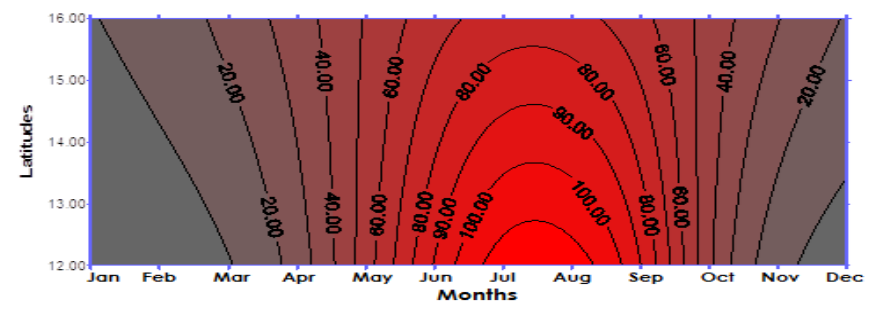

Figure 32: Spatio-temporal occurrences of MCS over Sokoto from 1981-1990.

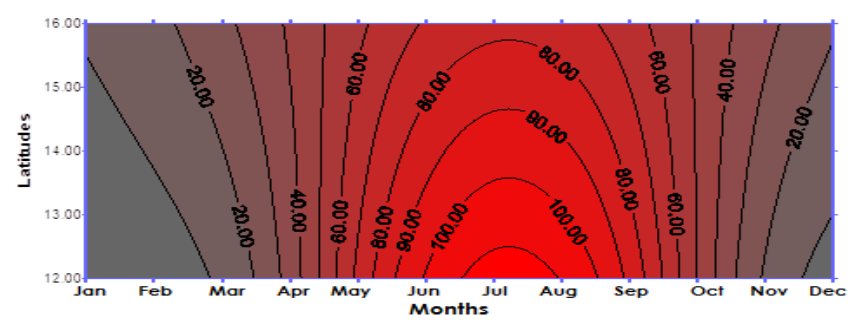

Figure 33: Spatio-temporal occurrences of MCS over Sokoto from 1991-2000.

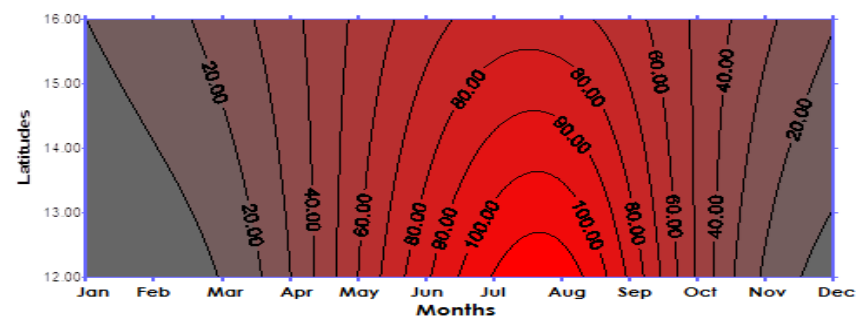

Figure 34: Spatio-temporal occurrences of MCS over Sokoto from 2001-2010.

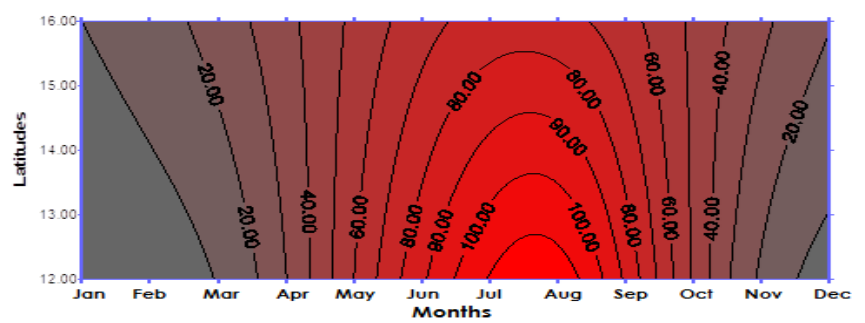

Figure 35: Spatio-temporal occurrences of MCS over Jos from 1981-1990. 
Citation: Ochei MC, Oluleye A (2017) Climate Variability Impact on the Frequency of Occurrence of Mesoscale Convective Systems in Northern Nigeria. J Climatol Weather Forecasting 5: 213. doi:10.4172/2332-2594.1000213

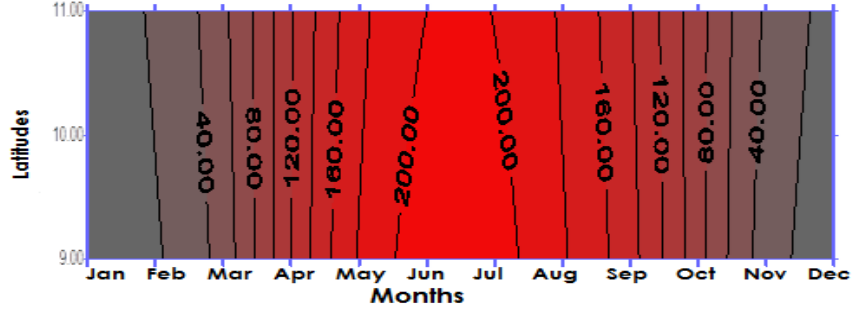

Figure 36: Spatio-temporal occurrences of MCS over Jos from 1991-2000.

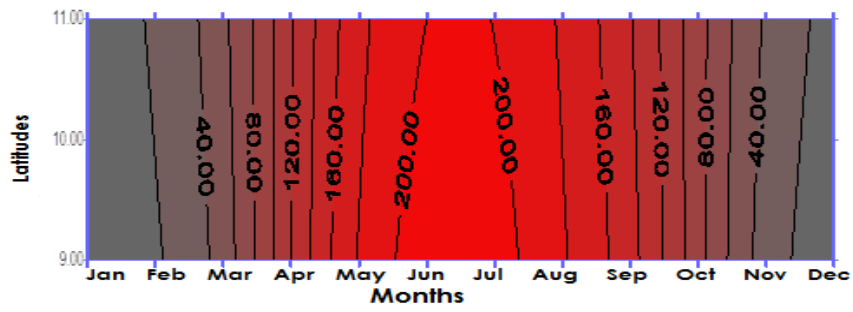

Figure 37: Spatio-temporal occurrences of MCS over Jos from 2001-2010.

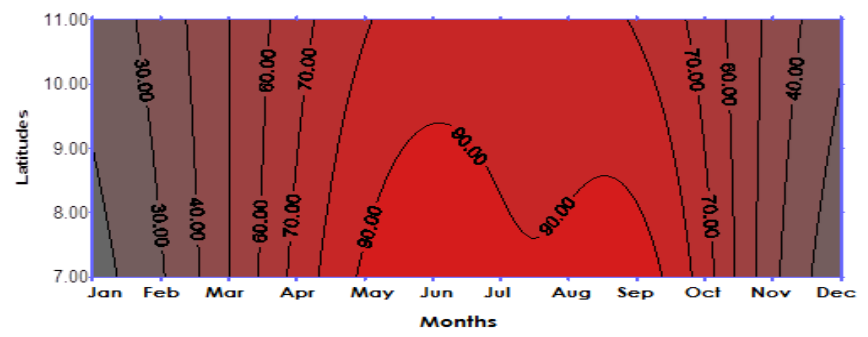

Figure 38: Spatio-temporal occurrences of MCS over llorin from 1981-1990.

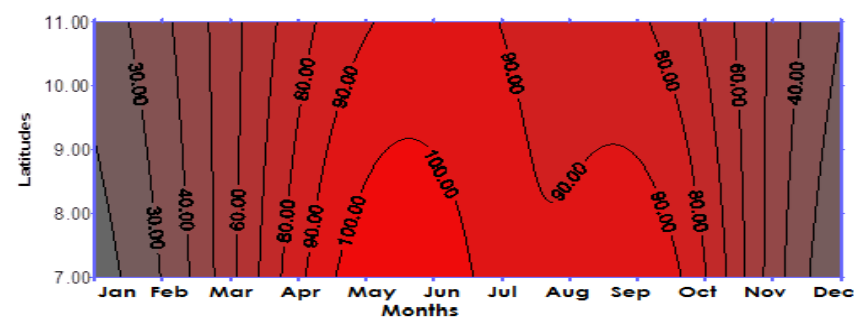

Figure 39: Spatio-temporal occurrences of MCS over llorin from 1991-2000.

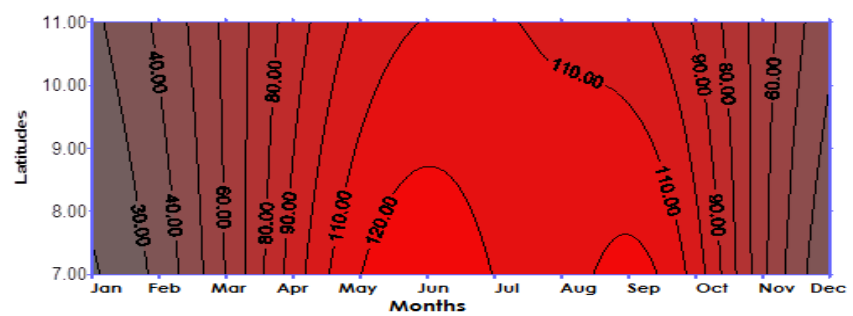

Figure 40: Spatio-temporal occurrences of MCS over llorin from 2001-2010.

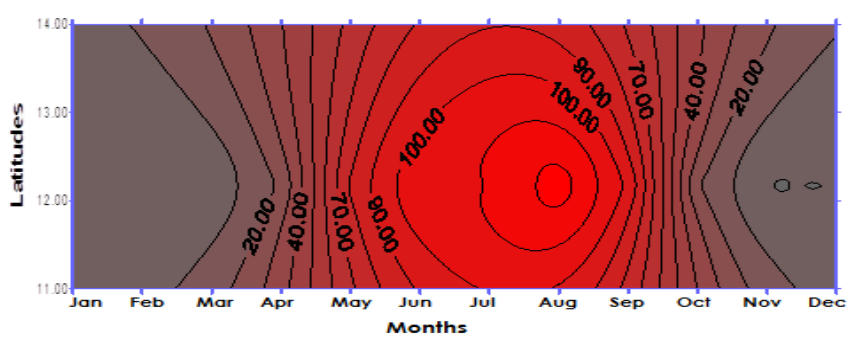

Figure 41: Spatio-temporal occurrences of MCS over Gusau from 1981-1990.

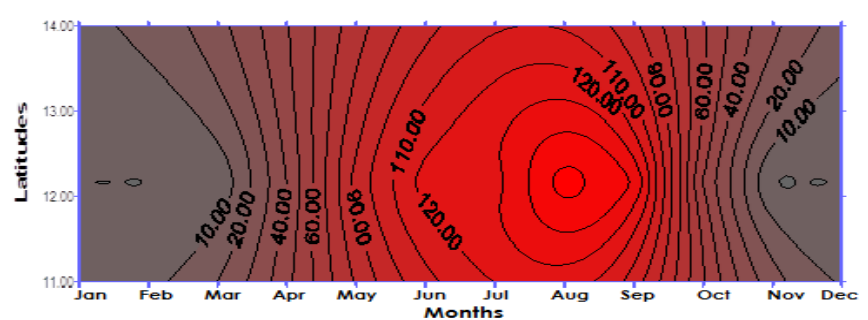

Figure 42: Spatio-temporal occurrences of MCS over Gusau from 1991-2000.

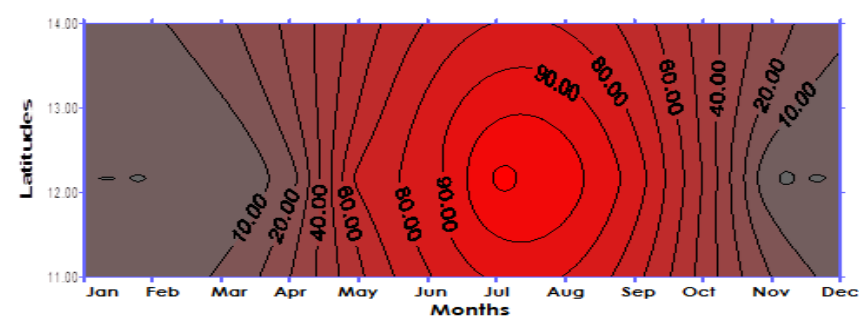

Figure 43: Spatio-temporal occurrences of MCS over Gusau from 2001-2010.

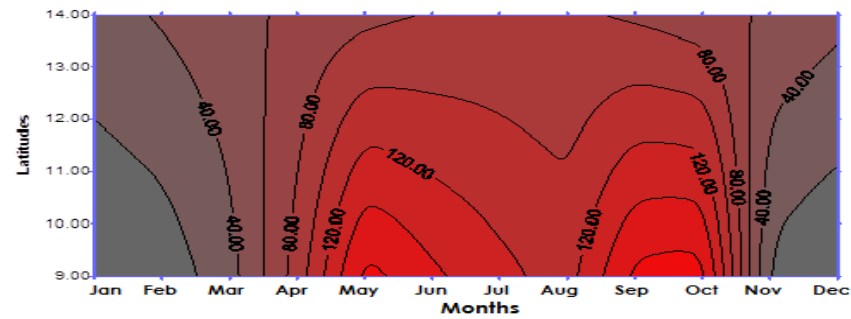

Figure 44: Spatio-temporal occurrences of MCS over Abuja from 1982-1990.

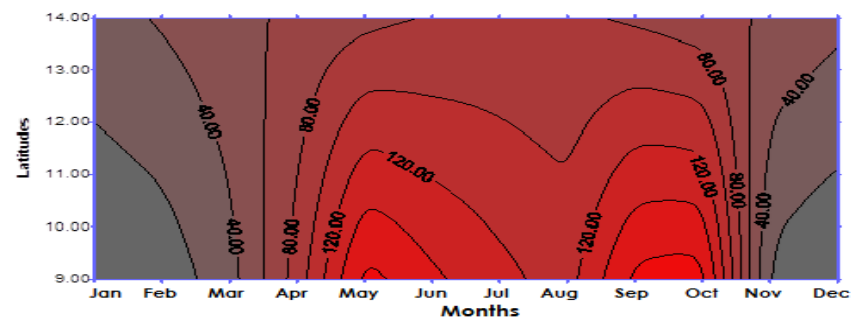

Figure 45: Spatio-temporal occurrences of MCS over Abuja from 1991-2000. 
Citation: Ochei MC, Oluleye A (2017) Climate Variability Impact on the Frequency of Occurrence of Mesoscale Convective Systems in Northern Nigeria. J Climatol Weather Forecasting 5: 213. doi:10.4172/2332-2594.1000213

Page 10 of 13

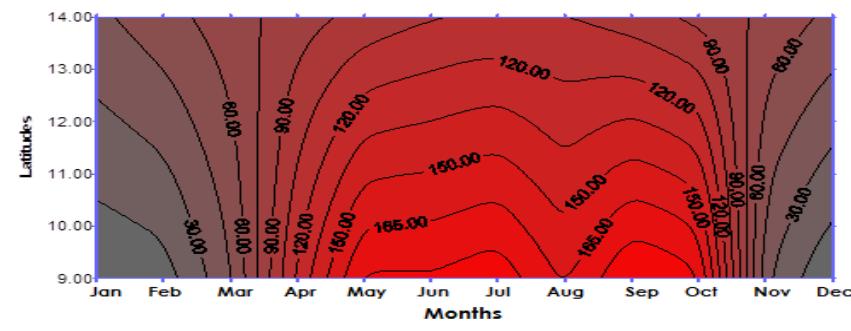

Figure 46: Spatio-temporal occurrences of MCS over Abuja from 2001-2010.

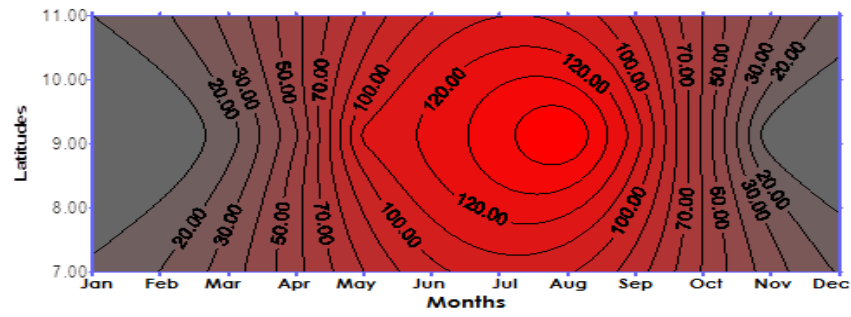

Figure 47: Spatio-temporal occurrences of MCS over Yola from 1981-1990.

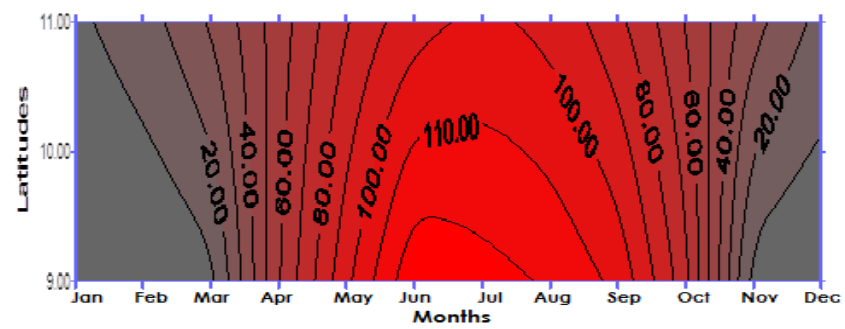

Figure 48: Spatio-temporal occurrences of MCS over Yola from 1991-2000.

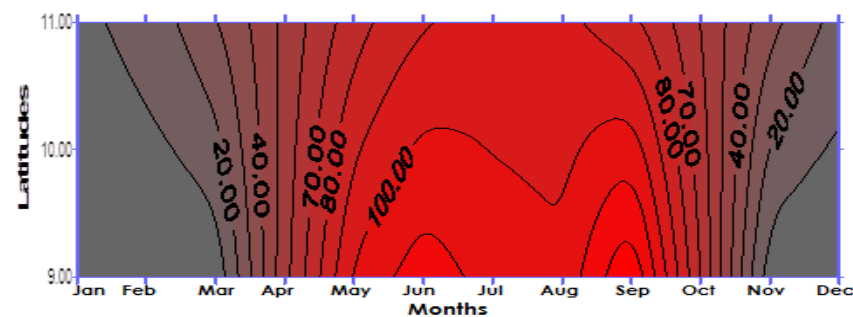

Figure 49: Spatio-temporal occurrences of MCS over Yola from 2001-2010.

a decreasing value from 120peals in the first decade to 100peals in the last decade. Though, this may be due to its closeness to the sahara desert of the sahel region which may have its own influence on the systems. Thus, the so-called "little dry season" in August should be renamed or replaced with "anomalous August weather" as cycles of wet and dry Augusts are observed as first proposed by Adefolalu [20].

\section{Coefficient of variation (Figures 50-52)}

\section{Discussion of the coefficient of variation of temperature}

The coefficient of variation as used to determine or compare the degree of variation of some parameters over a 30-years period in decadal. It showed that inland states (except Abuja) had high degree of hotness than some stations towards the extreme end of the north between 1981 and 1990; which are Maiduguri and Gusau as seen in Figure 50 and 51 . Though, the case was not the same in the other ten-years of 1991-2000 as shown in Figure 52 where only Maiduguri recorded the least degree of variation with about $0.85 \%$ compared to Abuja $=1.35 \%$, Gusau $=1.5 \%$ and Ilorin $=1.35 \%$.

\section{Coefficient of variation of rainfall}

The coefficient of variation for rainfall as shown in (Figures 53-55) revealed various degrees of variations with respect to zones and time. The first ten-years of 1981-1990 showed that the extreme north-eastern part of Nigeria which housed Potiskum and Maiduguri as pictured in Figure 53 had the highest percentage of degree of variation which ranges between $24 \%$ and $30 \%$. While the central states of Abuja and Jos recorded as low as $9 \%$ within the same period of time. Figure 54 for 1991-2000 showed that about two-third of the study areas had an average of about $17.5 \%$ in the degree of variation but Jos, Abuja and the extreme eastern part of Yola recorded the least variation of $11 \%$ within the same period. But Figure 55 which is the degree of variation for the last decade revealed that the north-western part of Gusau recorded as

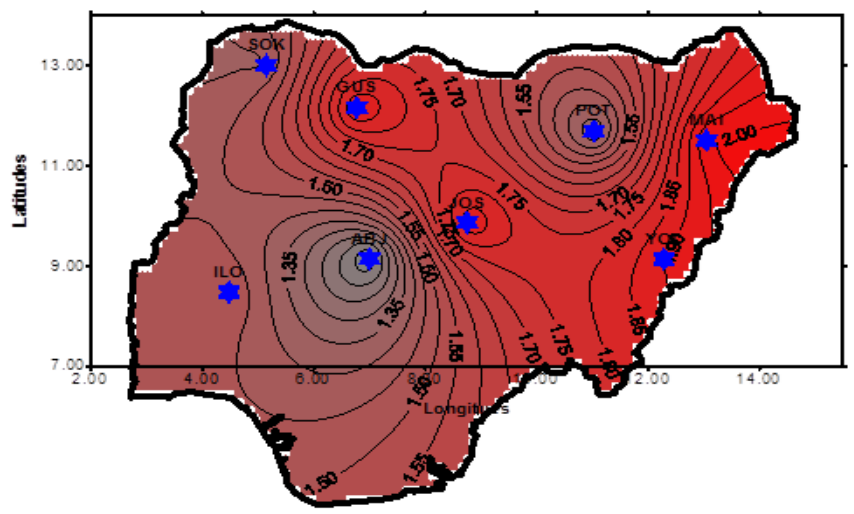

Figure 50: Contour map of coefficient of variation for temperature from 1981 1990

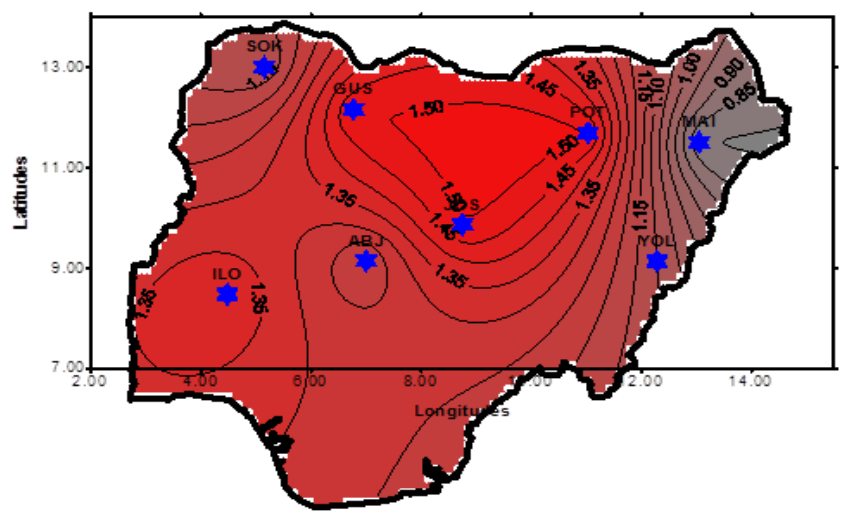

Figure 51: Contour map of coefficient of variation for temperature from 19912000. 
Citation: Ochei MC, Oluleye A (2017) Climate Variability Impact on the Frequency of Occurrence of Mesoscale Convective Systems in Northern Nigeria. J Climatol Weather Forecasting 5: 213. doi:10.4172/2332-2594.1000213

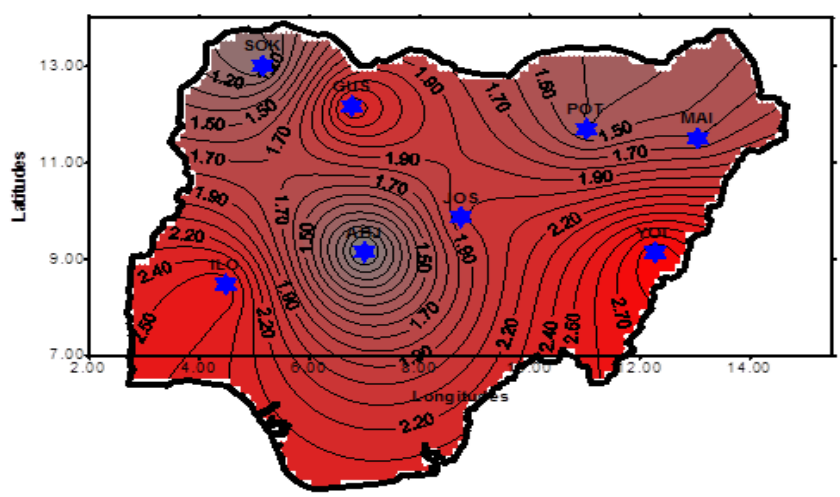

Figure 52: Contour map of coefficient of variation for temperature from 20012010

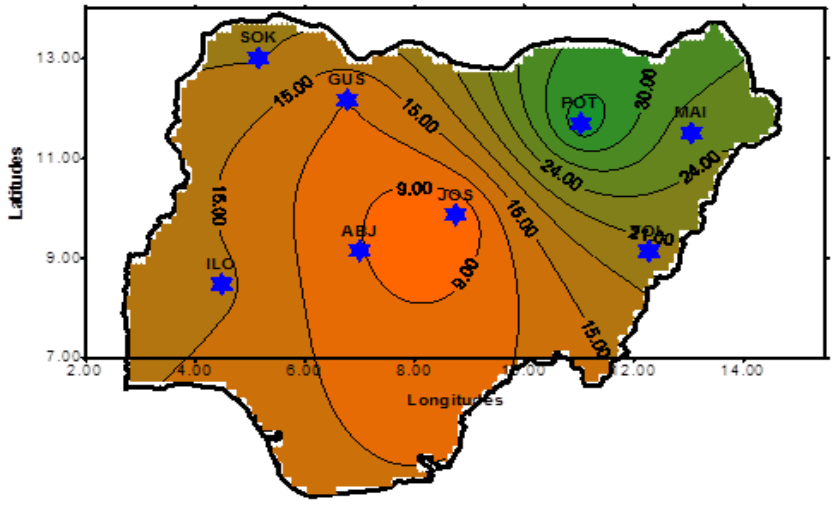

Figure 53: Contour map of coefficient of variation for rainfall from 1981-1990

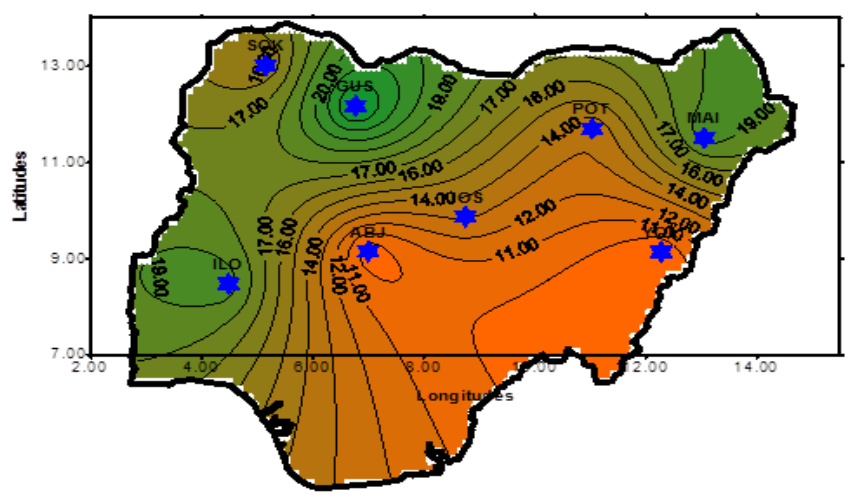

Figure 54: Contour map of coefficient of variation for rainfall from 1991-2000.

high as $34 \%$ while the features of the central states still remain the same as the zone that records least percentage degree of variation in rainfall.

\section{Coefficient of variation of relative humidity}

Adefolalu [20] illustrated the significant difference in mean value of relative humidity between north and south; with the seasonal variations being more pronounced in the north than the southern part of Nigeria.
In comparing the degree of hotness in Figures 50-52 with that of the relative humidity in Figures 56-58, there seems to be a unison with the general saying or knowledge of "the higher the temperature the lower the relative humidity and vice-versa". Potiskum and Maiduguri are some of the stations with least temperature percentage of coefficients of variation as seen in Figure 50 recorded the highest degree of variation in percentage for relative humidity as shown in Figure 56 while Ilorin in Figure 52 and Jos in Figures 51 showed an increase in the degree of variation for temperature but a decrease in relative humidity as seen in Figure 57 and 58 respectively.

Mesoscale Convective Systems varies in season and locations over West Africa and indeed Nigeria. In a bid to quantifying the regions of MCSs dominance and to study their spatial behaviour, we followed on the earlier sub-divisions into zones. Figures 59-61 showed that there was a noticeable difference in the number of MCSs over the zones closer to the coastal regions than the extreme northern parts. From the Figures 59-61 observed, the number of mesoscale convective system occurrences had a continuous decrease in number from 550 times from 1981-1990 to about 400 times between 2001 and 2010 for north-eastern stations of Potiskum and Maiduguri. But the reverse was the case in stations south of $10^{\circ} \mathrm{N}$ as it continuously increases from $800-1250$ times (Abuja), 800-1000 times (Ilorin) and 950-1100 times (Jos) from 1981-2010. Summarily, the number of mesoscale convective systems occurrences reduces by 150-times from 1981-2010 in the north-eastern part of Nigeria andFigure 50 also reduces by $50-100$ times in the north-

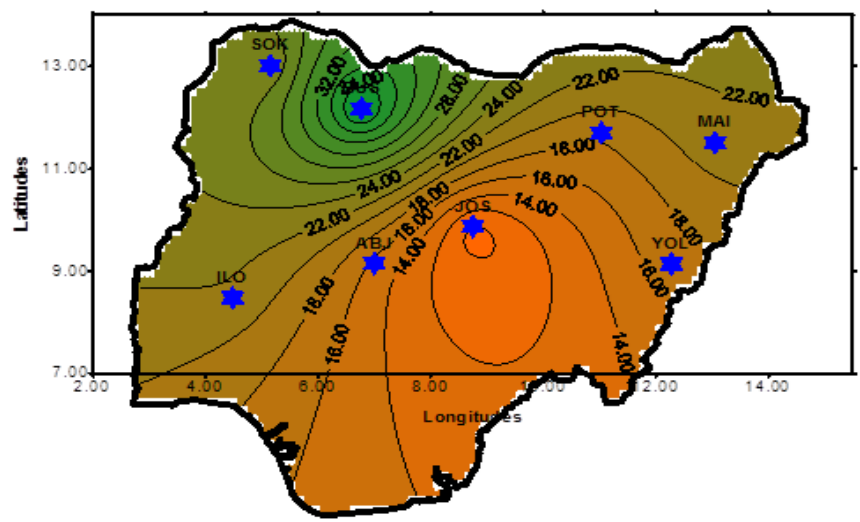

Figure 55: Contour map of coefficient of variation for rainfall from 2001-2010.

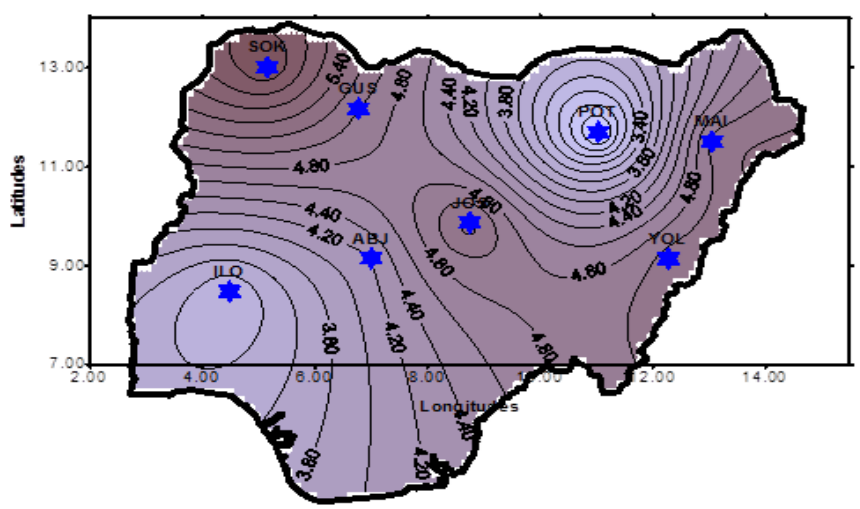

Figure 56: Contour map of coefficient of variance for relative humidity from 1981-1990. 
Citation: Ochei MC, Oluleye A (2017) Climate Variability Impact on the Frequency of Occurrence of Mesoscale Convective Systems in Northern Nigeria. J Climatol Weather Forecasting 5: 213. doi:10.4172/2332-2594.1000213

western parts (Sokoto and Gusau) of Nigeria but increases with about $150-450$ times in the number of occurrences for areas south of $10^{\circ} \mathrm{N}$. And this is in line with study of Orisakwe [6] who discovered that the percentage contribution of the convective systems have reduced drastically, thus, making the percentage contribution of monsoon rainfall to be estimated at a whopping $27.5 \%$.

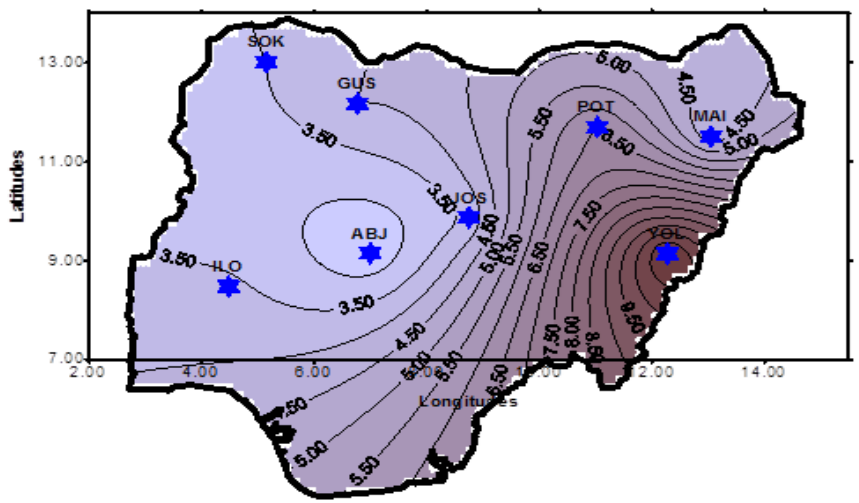

Figure 57: Contour map of coefficient of variance for relative humidity from 1991-2000

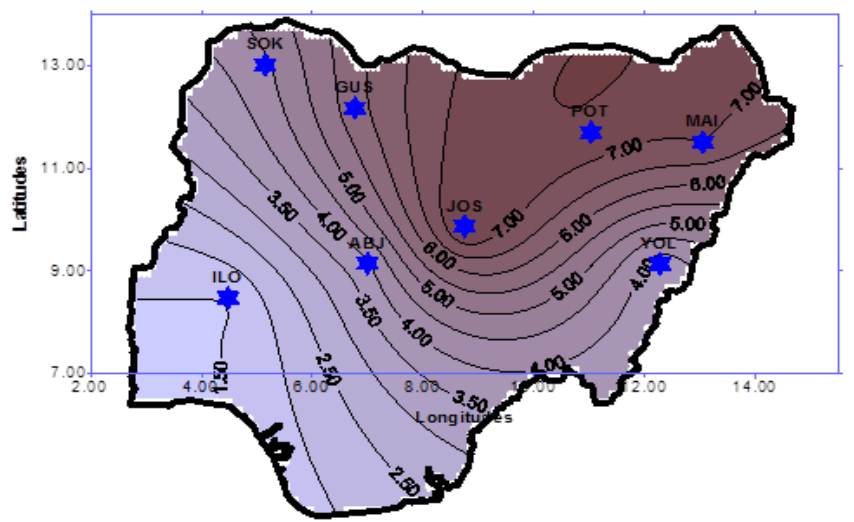

Figure 58: Contour map of coefficient of variance for relative humidity from 2001-2010.

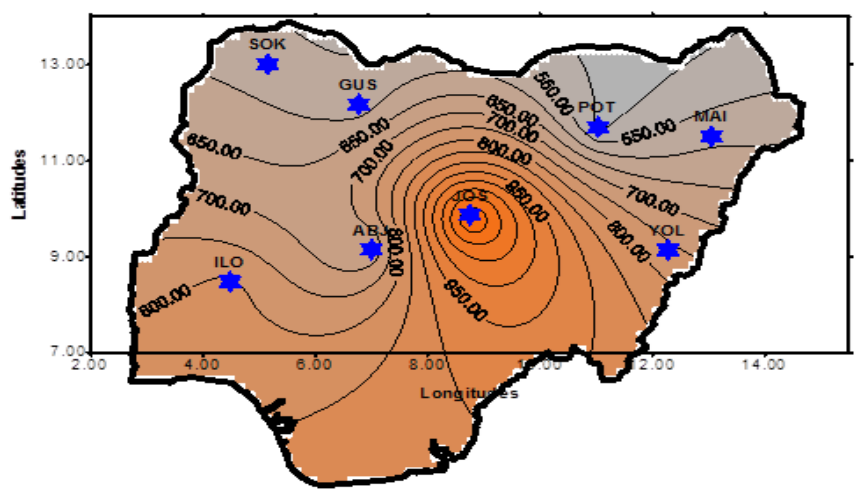

Figure 59: Contour map of number of mesoscale occurrence from 1981-1990.

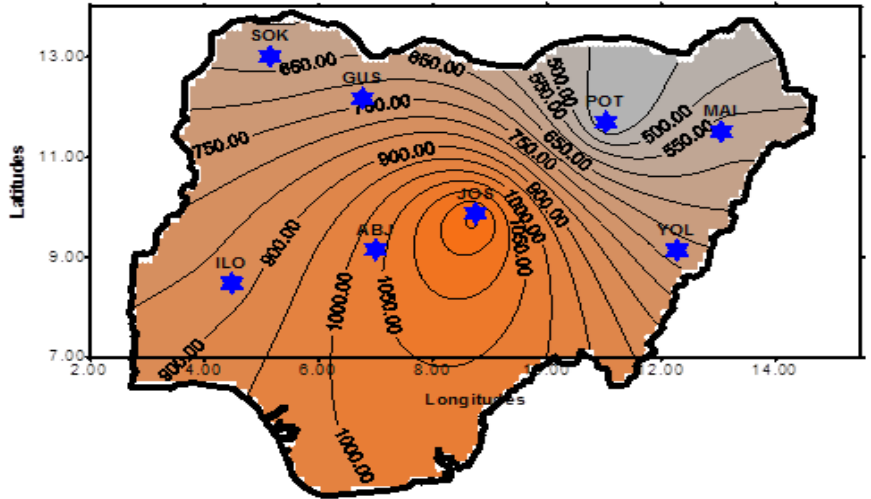

Figure 60: Contour map of number of mesoscale occurrence from 19912000.

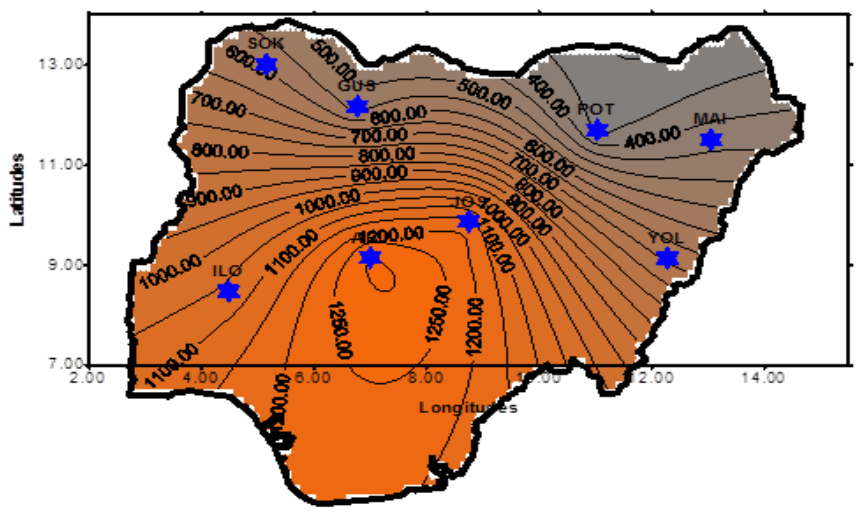

Figure 61: Contour map of number of mesoscale occurrence from 2001-2010.

\section{Conclusion}

Summarily, it can be deduced from above correlation graphs of the eight (8) stations in the northern part of Nigeria that there were increases in the trend of rainfall as a result of high contribution of mesoscale convective systems in the second decade (1991-2000) for the four stations in the extreme northern parts of the country (Gusau, Potiskum, Maiduguri and Sokoto). But there were decreases in the third decade (2001-2010) around 'Sudan savanah' of Sokoto and lake Chad province of Maiduguri which experienced more decline in mesoscale contribution within this period as compared to Gusau and Potiskum which are further inland than the earlier mentioned stations. But the Guinea savannah region which houses Ilorin, Abuja, Jos and Yola showed increases in the occurrences of mesoscale activities just as decreases are been felt in the extreme north. The occurrences of MCSs over years also reduces with almost one-third from 1981 to 2010 around Maiduguri and Potiskum axes; while Sokoto and Gusau recorded little or no change in the number of occurrences. Thus; showing that though they may all be located north of $10^{\circ} \mathrm{N}$ and towards the extreme but it seems that the effect of climate on the system is more felt in the northeastern part than the north-western part of Nigeria and thus indicate the possibility of monsoon type of precipitation depositing more than expected percentage contribution within the last ten (10) years of 20012010 when compared to about thirty (30) years ago. 
Citation: Ochei MC, Oluleye A (2017) Climate Variability Impact on the Frequency of Occurrence of Mesoscale Convective Systems in Northern Nigeria. J Climatol Weather Forecasting 5: 213. doi:10.4172/2332-2594.1000213

\section{References}

1. Adelekan IO (1998) Spatio-Temporal Variations in Thunderstorm Rainfall over Nigeria. Int J Climatol 18: 1273-1284.

2. Omotosho JB (1985) The separate contributions of line squalls, Thunderstorms and the Monsoon to the total Rainfall in Nigeria. J Climatol 5: 543-552.

3. Byers HR, Braham RR (1949) Some of Aspects of Thunderstorms during the Pre-Monsoon Season: A Preliminary Report. Int J Geosciences and Geomatics 3: 68-78.

4. Balogun EE (1981) Seasonal and Spatial variations in Thunderstorms activity over Nigeria. Weather 36: 192-197.

5. Omotosho JB (1976) A Survey of Temperature and Wind Fields over Tropical West Africa and their Relation to the Line Squall. BSc Project, Department of Geophysics, University of Reading, UK.

6. Orisakwe IC (2015) Disaggregation and Quantification of Rainfall Associated with three Rainfall Producing Systems in Nigeria. Unpublished M.Tech Thesis, FUTA, Nigeria, p: 47

7. Ochei MC, Orisakwe IC, Oluleye A (2015) Spatial, Seasonal and Inter-seasonal Variations of Thunderstorm Frequency over Nigeria. Afr J Env Sci Tech 9: 810833

8. Smull BF, Houze Jr RA (1987) Dual-Doppler radar analysis of a midlatitude squalline with a trailing region of stratiform rain. J Atmos Sci 44: 2128-2149.

9. Kingsmill DE, Wakimoto RM (1991) Kinematic, Dynamic and Thermodynamic Analysis of a Weakly Sheared severe thunderstorm over northern Alabama. Mon Wea Rev 119: 262- 297.

10. Biggerstaff MI, Houze Jr RA (1993) Kinematics and microphysics of the transition zone of a midlatitude squall-line system. J Atmos Sci 50: 3091- 3110.

11. Smull BF, Augustine JA (1993) Multiscale analysis of a mature mesoscale convective complexes. Mon Wea Rev 121: 103- 132.

12. Anderson CJ, Arritt RW (1998) Mesocale Convective Complexes and Persistent Elongated Convective Systems over the United States during 1992 and 1993. Mon Wea Rev 126: 578-599.
13. Osborn HB, Reynolds W (1963) Convective Storm Patterns in the southwestern United States. Bull Int Assoc Sci Hydrol 128: 3413-3436.

14. Changnon SA (2001) Damaging Thunderstorm Activity in the United States. Bull Amer Meteor Soc 82:597-608.

15. Changnon SA (2001) A National Index of Losses Caused by Weather and Climate Extremes. Phys Geogr 18: 1-29.

16. Odjugo PAO, Ikhuoria Al (2004) The Impact of Climate Change and Anthropogenic Factors on Desertification in the Semi-Arid Region of Nigeria. Global J Env Sci 2: 118-126.

17. Adefolalu DO (2007) Climate Change and Economic Sustainability in Nigeria In: International Conference on Climate Change and Economic Sustainability held at Nnamdi Azikwe University, Nigeria pp: 1-12.

18. Ayansina A, Ogunbo S (2009) GIS Approach in Assessing Seasonal Variability in Guinea Savannah Part of Nigeria. $7^{\text {th }}$ FIG Regional Conference, Vietnam, p: 16.

19. Ekpoh IJ (2007) Climate and Society in Northern Nigeria: Rainfall Variability and Farming. The Int J Series on Tropical Issues 8: 157-162.

20. Adefolalu DO (1972) On the Mean Equivalent Potential Temperature of the Tropical Atmosphere and the Little Dry Season of West Africa. Nig Quart Meteor Mag 2: 15-40.

21. Riehl H (1954) Tropical Meteorology. New York, McGraw-Hill, p: 392.

22. Thompson BW (1965) The Climate of Africa. New York, Oxford Press, p: 132.

23. Garnier BJ (1971) Weather Conditions in Nigeria. Climatological Series: 2 Department of Geography, McGill University. 13: 101-135.

24. Omotosho JB (1983) Prediction of Maximum Gusts in West African Line Squalls. Nig Met Journ 1: 94-100.

25. Eludoyin (2009) Monthly Variation in the 1985-1994 and 1995-2004 Rainfal Distribution over Five Selected Synoptic Stations in Western Nigeria. J Meteor Clim Sci 7: 11-22. 